\title{
Ruta Essential Oils: Composition and Bioactivities
}

\author{
Lutfun Nahar ${ }^{1, *(D)}$, Hesham R. El-Seedi ${ }^{2}$, Shaden A. M. Khalifa ${ }^{3}$, Majid Mohammadhosseini 4 (D) \\ and Satyajit D. Sarker $5, *$ (D)
}

1 Laboratory of Growth Regulators, Institute of Experimental Botany ASCR \& Palacký University, Šlechtitelů 27, 78371 Olomouc, Czech Republic

2 Biomedical Centre (BMC), Pharmacognosy Group, Department of Pharmaceutical Biosciences, Uppsala University, Box 591, SE-751 24 Uppsala, Sweden; hesham.el-seedi@farmbio.uu.se

3 Department of Molecular Biosciences, The Wenner-Gren Institute, Stockholm University, SE-106 91 Stockholm, Sweden; shaden.khalifa.2014@gmail.com

4 Department of Chemistry, College of Basic Sciences, Shahrood Branch, Islamic Azad University, Shahrood, Iran; majidmohammadhosseini@yahoo.com

5 Centre for Natural Products Discovery (CNPD), School of Pharmacy and Biomolecular Sciences, Liverpool John Moores University, James Parsons Building, Byrom Street, Liverpool L3 3AF, UK

* Correspondence: drnahar@live.co.uk (L.N.); S.Sarker@ljmu.ac.uk (S.D.S.); Tel.: +44-(0)-1512312096 (S.D.S.)

check for updates

Citation: Nahar, L.; El-Seedi, H.R.; Khalifa, S.A.M.; Mohammadhosseini, M.; Sarker, S.D. Ruta Essential Oils: Composition and Bioactivities. Molecules 2021, 26, 4766. https:// doi.org/10.3390/molecules26164766

Academic Editors: Marcello Iriti and Md. Moshfekus Saleh-E-In

Received: 16 July 2021

Accepted: 4 August 2021

Published: 6 August 2021

Publisher's Note: MDPI stays neutral with regard to jurisdictional claims in published maps and institutional affiliations.

Copyright: (c) 2021 by the authors. Licensee MDPI, Basel, Switzerland. This article is an open access article distributed under the terms and conditions of the Creative Commons Attribution (CC BY) license (https:// creativecommons.org/licenses/by/ $4.0 /)$.

\begin{abstract}
Ruta L. is a typical genus of the citrus family, Rutaceae Juss. and comprises ca. 40 different species, mainly distributed in the Mediterranean region. Ruta species have long been used in traditional medicines as an abortifacient and emmenagogue and for the treatment of lung diseases and microbial infections. The genus Ruta is rich in essential oils, which predominantly contain aliphatic ketones, e.g., 2-undecanone and 2-nonanone, but lack any significant amounts of terpenes. Three Ruta species, Ruta chalepensis L., Ruta graveolens L., and Ruta montana L., have been extensively studied for the composition of their essential oils and several bioactivities, revealing their potential medicinal and agrochemical applications. This review provides a systematic evaluation and critical appraisal of publications available in the literature on the composition and bioactivities of the essential oils obtained from Ruta species and includes a brief outlook of the potential applications of nanotechnology and chitosan-based products of Ruta essential oils.
\end{abstract}

Keywords: Ruta; Rutaceae; Ruta angustifolia; Ruta chalepensis; Ruta graveolens; Ruta montana; Ruta tuberculate; essential oils; 2-nonanone; 2-undecanone; bioactivity

\section{Introduction}

The genus Ruta L. belongs to the tribe Ruteae of the family Rutaceae Juss. and comprises ca. 40 different accepted species, which are native to or naturalized in many countries worldwide, especially in African, Asian, and European countries, e.g., Algeria, China, Iraq, Italy, Libya, Morocco, Portugal, Spain, Syria, and Tunisia, and have been introduced in the countries of North and South America [1,2]. However, the greatest distribution of Ruta species is found in the Mediterranean region. It can also be noted that the number of Ruta species as claimed by various authors may vary from as few as eight to as many as 160 species. Ruta chalepensis L., Ruta graveolens L., and Ruta montana L. are the three most widely distributed and most extensively studied species of the genus Ruta.

The use of Ruta species in traditional medicines can be traced as far back as the 5th century BCE as documented by various famous authors like Hippocrates and Dioscorides [3], and the potential traditional medicinal value of these species is still appreciated in many countries as is evident from their continued use in the Ayurvedic, Unani, and Siddha medicines. In fact, various species of this genus have long been included in the European Pharmacopoeia. Traditional medicinal uses of Ruta species include their uses mainly as an abortifacient and emmenagogue and in the treatment of lung diseases and microbial infections (Figure 1) [3,4]. Moreover, Ruta species have the potential for use as a potassium 
channel blocker in the treatment of neuromuscular diseases, anxiety, and dysmenorrhea. In addition to the presence of several bioactive alkaloids, coumarins (especially furanocoumarins), and flavonoids (mainly quercetin and its derivatives) in Ruta species, many of which are chemotaxonomically characteristic of the family Rutaceae, the species of this genus are also rich in essential oils, which contribute to their aromatic, agrochemical, and medicinal properties [4-6]. This review systematically evaluates and critically appraises the literature available to date on the composition and bioactivities of the essential oils obtained from Ruta species and includes a brief overview of the potential applications of nanotechnology and chitosan-based products of Ruta essential oils.

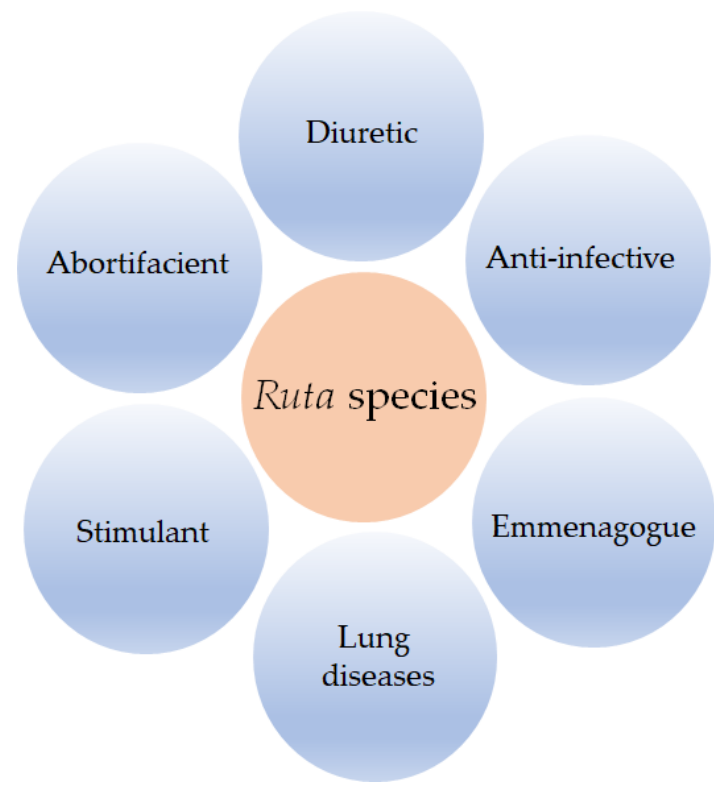

Figure 1. Major medicinal applications of Ruta species in traditional medicines.

\section{Composition of Ruta Essential Oils}

Ruta species are aromatic plants, and the relevant aromaticity is offered by the essential oils they produce. Essential oils are often a complex mixture of several compounds of various chemical classes, e.g., monoterpenes, sesquiterpenes, aliphatic alcohols, ketones, aldehydes, acids, and simple benzenoids. Generally, gas chromatography-flame ionization detection (GC-FID), gas chromatography-mass spectrometry (GC-MS), and gas chromatography-tandem mass spectrometry (GC-MS/MS) analytical techniques are used for the separation and identification of individual components present in essential oils, and these techniques provide qualitative and quantitative information required for the chemical profiling and quality control of essential oils [7].

From the studies on the composition of the essential oils of Ruta species, it appears that these essential oils, unlike many other plant essential oils, generally lack terpene components, but predominantly possess aliphatic ketones and some minor aliphatic alcohols. Based on the studies conducted on the dried or fresh plant materials of Ruta species (Table 1) [8-73], it is apparent that the long-chain aliphatic ketones, e.g., 2-undecanone (most abundant), 2-nonanone, 2-dodecanone, and 2-decanone (Figure 2) are the major components of Ruta essential oils. However, there are a few exceptions reported in the literature, for example, the air-dried aerial parts of $R$. graveolens from China were found to contain long-chain aliphatic esters like 2-undecanol acetate (19.2\%) and 2-undecanol 2-methylbutyl ester (8.9\%) [8], and the air-dried leaves of $R$. chalepensis from Beja (Tunisia) to possess menthol (43.9\%), linalool (42.1\%), and 2-hexanal (5.8\%) as major components of the essential oil [9]. Similarly, terpenes like limonene and $\beta$-caryophyllene have also been found in reasonable amounts in some Ruta samples, e.g., the essential oils from $R$. chalepensis samples collected in Italy and Morocco showed the presence of limonene (1.8-12.8\%) [10-13] and 
$\beta$-caryophyllene ( 3.4\%) was reported from the R. graveolens essential oil from Peru [14] and from the essential oil of R. montana collected in Algeria [15].
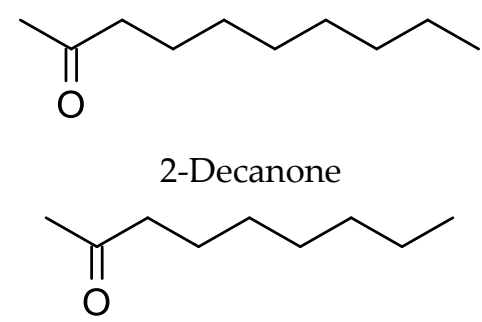

2-Nonanone
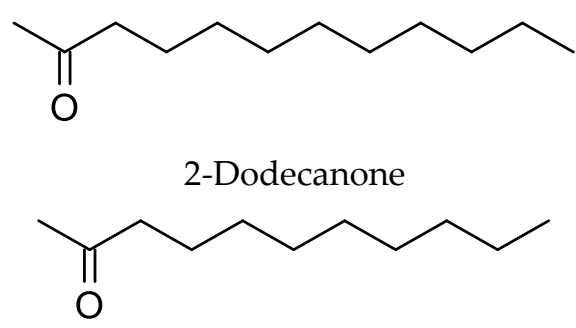

2-Undecanone

Figure 2. Major long-chain aliphatic ketones found in the Ruta essential oils.

In fact, because of the common occurrence of 2-undecanone as the major compound in the essential oils of Ruta species, this compound has been indicated as a suitable chemotaxonomic marker for the genus Ruta L. [15]. However, for the same reason, 2-nonanone could also be another marker compound for the chemotaxonomic study of the genus Ruta.

Most of the studies to date have been carried out with the whole aerial parts (fresh or dried), without differentiating flowers, fruits, leaves, and stems. However, there are a handful of reports (Table 1) available on the investigation of essential oils of individual parts/organs of Ruta species to understand the comparative chemical profiles and extraction yields. The roots of Ruta species have somehow been neglected as a source of any essential oil, but a genetically transformed root sample of $R$. graveolens was found to produce a percentage yield of $0.23 \%$ essential oil and to possess geijerene (67.0\%) (Figure 3 ) as the major compound in its essential oil [16], and the root essential oil of $R$. chalepensis grown in Poland was found to biosynthesize octyl acetate, methyl decanoate, and phytyl acetate as major components [17].<smiles>C=CC1(C)CCC=CC1C(=C)C</smiles>

Figure 3. Structure of geijerene.

The essential oils of $R$. chalepensis, including its subspecies and varieties, e.g., $R$. chalepensis subsp. angustifolia (Pers.) P. Cout., R. chalepensis var. bracteosa (DC) Boiss., and $R$. chalepensis subsp. latifolia (Salisb.) Linds. [10,11,15,17-49], and another species, $R$. graveolens $[8,16,18,50-66]$ collected from different parts of the world have been extensively investigated, and considerable variations have been observed both in the yield (\%) of essential oils, and their qualitative and quantitative chemical profiles (Table 1). Nevertheless, there are a good number of reports on the analysis of essential oil produced by $R$. montana (Table 1) $[41,62,67-73]$. There appears to be only one report each on the essential oil analysis of the species, R. angustifolia Pers. and R. tuberculata Forssk. [18]. However, R. angustifolia Pers. may actually be one of the subspecies of $R$. chalepensis rather than a separate species.

There have been significant inter- and intra-species differences observed in the yield (\%) and major composition of the essential oils of the Ruta species (Table 1). Differences in chemical profiles and yields of the Ruta essential oils have been observed because of the differences in geographical origins, collection times (e.g., flowering and post-flowering stages), climatic conditions, seasonal variations, processing methods, stress level, and extraction protocols $[15,40,51,54,55]$. Ruta samples collected even in a single country, but from different locations, showed noticeable differences in yields and composition of the essential oils. For example, the essential oils of Ruta samples collected from different locations in Tunisia demonstrated considerable differences both in \% yield and chemical 
composition [9,36-40,61,62] (Table 1), and a similar observation could be made for the $R$. montana samples collected from various sparts of Algeria [67]. Considerable variations in the essential oil yields (\%) and chemical profiles have also been observed between cultivated and wild-growing plant materials from Ruta species [44]. However, hardly any difference in \% yield of essential oils in the leaves of wild-grown and micropropagated samples of $R$. graveolens ( $0.80 \%$ and $0.84 \%$, respectively) could be observed [57].

Table 1. Major components of the essential oils of Ruta species from different geographical origins.

\begin{tabular}{|c|c|c|c|c|}
\hline Ruta Species & $\begin{array}{c}\text { Geographical } \\
\text { Sources (Region) }\end{array}$ & Plant Parts (Yield) & Major Components & References \\
\hline $\begin{array}{l}\text { Ruta angustifolia } \\
\text { Pers. }\end{array}$ & $\begin{array}{c}\text { Algeria } \\
\text { (Tlemcen) }\end{array}$ & $\begin{array}{l}\text { Air-dried aerial parts } \\
\qquad(1.49 \%)\end{array}$ & $\begin{array}{l}\text { 2-Undecanone }(82.5 \%) \text { and 2-decanone } \\
(10.0 \%)\end{array}$ & [18] \\
\hline \multirow[t]{16}{*}{ Ruta chalepensis L. } & $\begin{array}{c}\text { Algeria } \\
\text { (Ain-delfa) }\end{array}$ & $\begin{array}{l}\text { Air-dried aerial parts } \\
\qquad(0.90 \%)\end{array}$ & $\begin{array}{c}\text { 2-Undecanone }(67.0 \%), 2 \text {-decanone }(9.0 \%), \\
6-\left(3^{\prime}, 5^{\prime} \text {-benzodioxyl)-2-hexanone }(6.3 \%),\right. \\
\text { and 2-dodecanone }(4.0 \%)\end{array}$ & [19] \\
\hline & $\begin{array}{l}\text { Algeria } \\
\text { (Blida) }\end{array}$ & $\begin{array}{l}\text { Air-dried aerial parts } \\
\qquad(0.40 \%)\end{array}$ & $\begin{array}{l}\text { 2-Undecanone }(35.5 \%) \text {, 2-methyl-1-decanol } \\
(8.6 \%) \text {, and } 2 \text {-dodecanone }(6.9 \%)\end{array}$ & [20] \\
\hline & Chile & $\begin{array}{l}\text { Air- and oven-dried } \\
\left(20^{\circ} \mathrm{C}\right) \text { aerial parts } \\
(0.30 \%)\end{array}$ & $\begin{array}{l}\text { 2-Nonanone (41.7\%) and 2-undecanone } \\
(40.1 \%)\end{array}$ & [21] \\
\hline & $\begin{array}{l}\text { Colombia } \\
\text { (Cacota) }\end{array}$ & $\begin{array}{l}\text { Shade-dried leaves } \\
\qquad(0.12 \%)\end{array}$ & $\begin{array}{l}\text { 2-Undecanone }(39.4 \%), 2 \text {-nonanone }(37.1 \%) \text {, } \\
\text { 2-decanone }(2.8 \%) \text {, and nonyl acetate }(2.2 \%)\end{array}$ & [22] \\
\hline & Cuba & $\begin{array}{l}\text { Air-dried aerial parts } \\
\qquad(0.30 \%)\end{array}$ & $\begin{array}{l}\text { 2-Undecanone }(34.9 \%) \text { and 2-nonanone } \\
(25.2 \%)\end{array}$ & [23] \\
\hline & Greece & $\begin{array}{l}\text { Air-dried aerial parts } \\
\qquad(1.10 \%)\end{array}$ & $\begin{array}{c}\text { 2-Methyloctyl acetate }(44.0 \%), \\
\beta \text {-phellandrene }(10.8 \%), 2 \text {-nonanol }(7.2 \%), \\
\text { and } \beta \text {-pinene }(6.4 \%)\end{array}$ & [24] \\
\hline & $\begin{array}{c}\text { Italy } \\
\text { (San Alessio) }\end{array}$ & Fresh flowers $(0.89 \%)$ & $\begin{array}{l}\text { 2-Nonanone }(44.9 \%), 2 \text {-undecanone }(44.9 \%), \\
\text { and limonene }(1.8 \%)\end{array}$ & [11] \\
\hline & & Fresh fruits $(1.40 \%)$ & $\begin{array}{l}\text { 2-Nonanone (51.8\%), and 2-undecanone } \\
(41.9 \%)\end{array}$ & [11] \\
\hline & & Fresh leaves $(1.10 \%)$ & $\begin{array}{c}\text { 2-Nonanone (69.9\%), 2-undecanone }(15.5 \%) \text {, } \\
\text { and limonene }(3.1 \%)\end{array}$ & [11] \\
\hline & & Fresh stems $(0.97 \%)$ & $\begin{array}{l}\text { 2-Nonanone }(51.3 \%), 2 \text {-undecanone }(33.0 \%) \text {, } \\
\text { and limonene }(3.7 \%)\end{array}$ & [11] \\
\hline & $\begin{array}{l}\text { Italy } \\
\text { (Cagliari) }\end{array}$ & $\begin{array}{l}\text { Air-dried aerial parts } \\
\qquad(0.36 \%)\end{array}$ & $\begin{array}{c}\text { 2-Undecanone }(\sim 56.0 \%), 2 \text {-nonanone } \\
\begin{array}{c}(\sim 36.0 \%), 2 \text {-decaone }(\sim 2.5 \%), \text { and 2-nonanol } \\
(\sim 2.0 \%)\end{array}\end{array}$ & [25] \\
\hline & $\begin{array}{c}\text { Italy } \\
\text { (Cagliari) }\end{array}$ & $\begin{array}{l}\text { Air-dried aerial parts } \\
\qquad(1.09 \%)\end{array}$ & $\begin{array}{c}\text { 2-nonanone }(25.3 \%), \text { 2-undecanone }(24.0 \%), \\
\text { limonene }(12.8 \%), \text { octyl acetate }(10.4 \%), \\
\text { geijerene }(5.7 \%), \text { and } 2 \text {-decaone }(3.7 \%)\end{array}$ & [12] \\
\hline & $\begin{array}{c}\text { Italy } \\
\text { (Monte Pisano) }\end{array}$ & $\begin{array}{l}\text { Air-dried aerial parts } \\
\qquad(0.79 \%)\end{array}$ & $\begin{array}{c}\text { 2-Nonanone }(56.7 \%), 2 \text {-nonanol }(3.5 \%) \text {, and } \\
\text { limonene }(2.2 \%)\end{array}$ & [13] \\
\hline & India & Fresh flowers $(0.69 \%)$ & $\begin{array}{c}\text { 2-Undecanone }(67.8 \%), 2 \text {-nonanone }(10.3 \%) \text {, } \\
\text { 2-decanone }(3.1 \%) \text {, and 2-nonyl acetate } \\
(2.8 \%)\end{array}$ & [26] \\
\hline & & Fresh fruits $(0.88 \%)$ & $\begin{array}{c}\text { 2-Undecanone }(60.0 \%), 2 \text {-dodecanone } \\
(11.6 \%), 2 \text {-nonanone }(5.2 \%) \text {, and 2-nonyl } \\
\text { acetate }(4.4 \%)\end{array}$ & [26] \\
\hline & & Fresh leaves $(0.56 \%)$ & $\begin{array}{c}\text { 2-Undecanone (41.3-47.7\%), 2-nonanone } \\
(13.8-33.6 \%), 2-\text {-nonyl acetate }(9.0-15.3 \%) \text {, } \\
\text { 2-decanone (2.6-3.1\%), and 2-dodecanone } \\
(0.7-2.2 \%)\end{array}$ & {$[26]$} \\
\hline
\end{tabular}


Table 1. Cont.

\begin{tabular}{|c|c|c|c|c|}
\hline Ruta Species & $\begin{array}{c}\text { Geographical } \\
\text { Sources (Region) }\end{array}$ & Plant Parts (Yield) & Major Components & References \\
\hline & Iran & $\begin{array}{l}\text { Air-dried aerial parts } \\
\qquad(1.3 \%)\end{array}$ & $\begin{array}{c}\text { 2-Undecanone }(52.5 \%), 2 \text {-nonanone }(24.1 \%), \\
\text { and nonyl acetate }(9.1 \%)\end{array}$ & [27] \\
\hline & Jordan & $\begin{array}{l}\text { Air-dried (in the } \\
\text { dark) aerial parts } \\
(0.83 \%)\end{array}$ & $\begin{array}{l}\text { 2-Cyclohexen-1-one,3-[(2,3,4,9 } \\
\text { tetrahydro-1H-pyrido[3,4 b]indole-1-yl) } \\
\text { methyl] }(45.9 \%) \text { and 2-nonanone }(19.5 \%)\end{array}$ & [28] \\
\hline & \multirow[t]{2}{*}{ Lebanon } & $\begin{array}{l}\text { Fresh leaves and } \\
\text { stems }(0.12 \%)\end{array}$ & $\begin{array}{l}\text { 2-Nonanone }(42.5 \%), \text { 2-undecaone }(41.4 \%) \text {, } \\
\text { and terpen-4-ol }(2.2 \%)\end{array}$ & [29] \\
\hline & & Fresh leaves $(0.12 \%)$ & $\begin{array}{c}\text { 2-Nonanone }(51.7 \%) \text { and 2-undecaone } \\
(36.7 \%)\end{array}$ & [29] \\
\hline & Mexico & Fresh aerial parts & $\begin{array}{c}\text { 2-Undecaone (43.7\%) and 2-nonanone } \\
(35.4 \%)\end{array}$ & {$[30]$} \\
\hline & $\begin{array}{c}\text { Morocco } \\
\text { (Central plateau) }\end{array}$ & $\begin{array}{l}\text { Shed-dried aerial } \\
\text { parts }(2.72 \%)\end{array}$ & $\begin{array}{c}\text { 2-Undecanone }(64.4 \%) \text {, piperonyl } \\
\text { piperazine }(11.9 \%), 2 \text {-decanone }(5.1 \%) \text {, and } \\
\text { 2-dodecanone }(4.5 \%)\end{array}$ & {$[31]$} \\
\hline & $\begin{array}{l}\text { Morocco } \\
\text { (High Atlas } \\
\text { Mountains) }\end{array}$ & $\begin{array}{l}\text { Air-dried leaves } \\
\qquad(0.56 \%)\end{array}$ & $\begin{array}{l}\text { 2-Undecaone }(49.1 \%), \text { 2-nonanone }(33.2 \%), \\
\text { limonene }(4.2 \%) \text {, and 2-decanone }(2.7 \%)\end{array}$ & [10] \\
\hline & Morocco & $\begin{array}{l}\text { Air-dried aerial parts } \\
\qquad(0.66 \%)\end{array}$ & 2-Undecaone (93.1\%) & [32] \\
\hline & $\begin{array}{l}\text { Palestine } \\
\text { (Jerusalem, Hebron } \\
\text { and Jenin) }\end{array}$ & $\begin{array}{l}\text { Shade-dried leaves } \\
\qquad(0.23 \%)\end{array}$ & $\begin{array}{l}\text { 2-Undecanone }(7.7-44.3 \%) \text { and 2-nonanone } \\
\qquad(8.2-43.0 \%)\end{array}$ & [33] \\
\hline & Peru & $\begin{array}{l}\text { Fresh aerial parts } \\
\qquad(0.22 \%)\end{array}$ & $\begin{array}{l}\text { 2-Undecanone (58.2\%) and 2-nonanone } \\
\qquad(25.3 \%)\end{array}$ & [14] \\
\hline & \multirow[t]{3}{*}{ Poland } & $\begin{array}{l}\text { Shade-dried leaves } \\
\qquad(0.26 \%)\end{array}$ & $\begin{array}{c}\text { 2-Undecanone }(50.0 \%), 2 \text {-nonanone }(35.0 \%), \\
\text { and geijerene }(9.2 \%)\end{array}$ & [17] \\
\hline & & $\begin{array}{l}\text { Shade-dried roots } \\
(0.19 \%)\end{array}$ & $\begin{array}{l}\text { Octyl acetate }(29.0 \%) \text {, methyl decanoate } \\
(22.1 \%) \text {, and phytyl acetate }(17.2 \%)\end{array}$ & [17] \\
\hline & & $\begin{array}{l}\text { Shade-dried stems } \\
\quad(0.82 \%)\end{array}$ & $\begin{array}{c}\text { 2-Decanone }(21.2 \%) \text {, geijerene }(19.2 \%), \\
\text { 2-nonanone }(16.1 \%) \text {, and 2-undecaone } \\
\qquad(9.1 \%)\end{array}$ & [17] \\
\hline & $\begin{array}{c}\text { Portugal } \\
\text { (Madeira island) }\end{array}$ & Fresh leaves $(0.32 \%)$ & $\begin{array}{l}\text { 2-Undecanone }(53.0 \%),(E) \text {-2-octenal } \\
(28.0 \%) \text {, and 2-nonanone }(10.0 \%)\end{array}$ & {$[34]$} \\
\hline & Spain & $\begin{array}{l}\text { Shade-dried aerial } \\
\text { parts }(0.43 \%)\end{array}$ & 2-Undecanone $(64.9 \%)$ & [35] \\
\hline & \multirow[t]{3}{*}{$\begin{array}{l}\text { Tunisia } \\
\text { (Sdira and } \\
\text { Thoujene) }\end{array}$} & $\begin{array}{l}\text { Shade-dried fruits } \\
\qquad(3.0 \%)\end{array}$ & $\begin{array}{c}\text { 2-Undecanone }(57.5 \text { and } 58.4 \%), \\
\text { 2-nonanone (19.0 and } 23.3 \%) \text {, and octyl } \\
\text { acetate (3.4 and } 5.1 \%)\end{array}$ & [36] \\
\hline & & $\begin{array}{l}\text { Shade-dried leaves } \\
\qquad(1.40 \%)\end{array}$ & $\begin{array}{l}\text { 2-Undecanone ( } 23.0 \text { and } 27.9 \%), 2 \text {-nonanone } \\
\text { (21.1 and } 16.7 \%) \text {, octyl acetate (26.6 and } \\
26.8 \%) \text {, and chalepensin ( } 3.0 \text { and } 2.3 \%)\end{array}$ & [36] \\
\hline & & $\begin{array}{l}\text { Shade-dried stems } \\
(0.31 \%)\end{array}$ & $\begin{array}{l}\text { 2-Undecanone ( } 31.9 \text { and } 37.7 \%), 2 \text {-nonanone } \\
\text { ( } 23.0 \text { and } 22.1 \%) \text {, octyl acetate (11.0 and } \\
12.1 \%) \text {, and decyl acetate (4.2 and } 5.4 \%)\end{array}$ & [36] \\
\hline & $\begin{array}{c}\text { Tunisia } \\
\text { (El Fahs region) }\end{array}$ & $\begin{array}{l}\text { Shade-dried aerial } \\
\text { parts }(0.30 \%)\end{array}$ & 2-Undecanone (87.2\%) & {$[37]$} \\
\hline & $\begin{array}{l}\text { Tunisia } \\
\text { (El Fahs) }\end{array}$ & Fresh flowers (1.75\%) & $\begin{array}{c}\text { 2-Undecanone }(89.9 \%) \text { and 2-decanone } \\
(4.2 \%)\end{array}$ & [38] \\
\hline
\end{tabular}


Table 1. Cont.

\begin{tabular}{|c|c|c|c|c|}
\hline Ruta Species & $\begin{array}{c}\text { Geographical } \\
\text { Sources (Region) }\end{array}$ & Plant Parts (Yield) & Major Components & References \\
\hline & & Fresh leaves $(0.69 \%)$ & $\begin{array}{c}\text { 2-Undecanone }(85.9 \%), 2 \text {-decanone }(5.6 \%), \\
\text { and piperazine }(3.0 \%)\end{array}$ & [38] \\
\hline & Tunisia (Thoujene) & $\begin{array}{l}\text { Shade-dried fruits } \\
\qquad(2.5 \%)\end{array}$ & $\begin{array}{l}\text { 2-Undecanone (58.4\%), 2-nonanone (19.1\%), } \\
\text { and 2-undecanol (4.1\%) }\end{array}$ & [39] \\
\hline & & $\begin{array}{l}\text { Shade-dried leaves } \\
\qquad(0.90 \%)\end{array}$ & $\begin{array}{c}\text { 2-Undecanone }(27.9 \%), 2 \text {-nonanone }(16.7 \%), \\
\text { octyl acetate }(26.8 \%) \text {, decyl acetate }(9.4 \%), \\
\text { and 2-nonanol }(3.8 \%)\end{array}$ & [39] \\
\hline & & $\begin{array}{l}\text { Shade-dried stems } \\
\qquad(0.30 \%)\end{array}$ & $\begin{array}{c}\text { 2-Undecanone }(37.7 \%) \text {, 2-nonanone }(22.1 \%), \\
\text { octyl acetate }(12.1 \%) \text {, decyl acetate }(5.4 \%), \\
\text { and } 2 \text {-undecanol }(2.9 \%)\end{array}$ & [39] \\
\hline & Tunisia (Beja) & $\begin{array}{l}\text { Air-dried leaves } \\
\quad(0.90 \%)\end{array}$ & $\begin{array}{c}\text { Menthol (43.9\%), linalool }(42.1 \%) \text {, and } \\
\text { 2-hexanal }(5.8 \%)\end{array}$ & [9] \\
\hline & Tunisia & $\begin{array}{l}\text { Air-dried aerial parts } \\
\text { at flowering and } \\
\text { post-flowering stages } \\
(0.70 \text { and } 0.50 \%, \\
\text { respectively }))\end{array}$ & $\begin{array}{c}\text { 2-Undecanone }(33.4-49.8 \%), \text { 2-heptanol } \\
\text { acetate }(13.5-15.4 \%) \text {, and } \alpha \text {-pinene } \\
(9.8-11.9 \%)\end{array}$ & {$[40]$} \\
\hline & \multirow[t]{2}{*}{$\begin{array}{c}\text { Tunisia } \\
\text { (El Hamma) }\end{array}$} & $\begin{array}{l}\text { Shade-dried leaves } \\
(0.66 \%)\end{array}$ & $\begin{array}{l}\text { 2-Undeconone (48.6\%), 1-nonene }(18.4 \%) \text {, } \\
\text { and 2-nonanone }(3.5 \%)\end{array}$ & {$[41]$} \\
\hline & & $\begin{array}{l}\text { Share-dried stems } \\
\qquad(0.66 \%)\end{array}$ & $\begin{array}{l}\text { 2-Undeconone }(50.6 \%), 1 \text {-nonene }(10.9 \%) \text {, } \\
\text { 2-nonanone }(5.4 \%) \text { and 1-dodecene }(3.7 \%)\end{array}$ & {$[41]$} \\
\hline & $\begin{array}{l}\text { Tunisia } \\
\text { (Kef) }\end{array}$ & $\begin{array}{l}\text { Air-dried leaves } \\
\qquad(0.85 \%)\end{array}$ & $\begin{array}{c}\text { Menthol (49.9\%), linalool (31.1\%), and } \\
\text { 2-hexanal (5.2\%) }\end{array}$ & [42] \\
\hline & \multirow[t]{4}{*}{$\begin{array}{l}\text { Tunisia } \\
\text { (El Fahs) }\end{array}$} & $\begin{array}{l}\text { Shade-dried flowers } \\
(0.77 \%)\end{array}$ & 2-Undecanone (100\%) & {$[43]$} \\
\hline & & $\begin{array}{l}\text { Shade-dried leaves } \\
(0.55 \%)\end{array}$ & $\begin{array}{l}\text { 2-Undecanone }(69.2 \%) \text {, camphor }(2.5 \%) \text {, } \\
\text { 2-decanone }(2.4 \%) \text { and 2-dodecanone }(2.0 \%)\end{array}$ & {$[43]$} \\
\hline & & Fresh leaves $(0.98 \%)$ & $\begin{array}{c}\text { 2-Undecanone }(77.2 \%), 2 \text {-decanone }(9.0 \%), \\
\text { and 2-dodecanone }(2.4 \%)\end{array}$ & [43] \\
\hline & & $\begin{array}{l}\text { Shade-dried stems } \\
\qquad(0.70 \%)\end{array}$ & Pulegone (32.1\%) & {$[43]$} \\
\hline & \multirow[t]{4}{*}{$\begin{array}{c}\text { Tunisia } \\
\text { (Mountain Traza) }\end{array}$} & $\begin{array}{l}\text { Air-dried flowers } \\
\quad(0.70-0.99 \%)\end{array}$ & $\begin{array}{l}\text { 2-Undecanone (44.1-60.5\%), 2-nonanol } \\
(21.5-36.4 \%) \text {, and 2-dodecanone (0.1-2.8\%) }\end{array}$ & {$[44]$} \\
\hline & & $\begin{array}{l}\text { Air-dried fruits } \\
\qquad(1.73 \%)\end{array}$ & $\begin{array}{l}\text { 2-Undecanone (0.17-41.0\%), 2-nonanol } \\
(0.86-11.6 \%) \text {, and 2-dodecanone (5.8-80.0\%) }\end{array}$ & {$[44]$} \\
\hline & & $\begin{array}{l}\text { Air-dried leaves } \\
(0.39-0.57 \%)\end{array}$ & $\begin{array}{l}\text { 2-Undecanone (33.5-36.6\%), 2-nonanol } \\
(28.1-45.1 \%) \text {, and 2-dodecanone }(0.1-0.2 \%)\end{array}$ & {$[44]$} \\
\hline & & $\begin{array}{l}\text { Air-dried stems } \\
(0.49-0.66 \%)\end{array}$ & $\begin{array}{l}\text { 2-Undecanone (26.7-33.5\%), 2-nonanol } \\
(28.1-40.5 \%) \text {, and 2-dodecanone (0.2-13.6\%) }\end{array}$ & [44] \\
\hline & $\begin{array}{c}\text { Tunisia } \\
\text { (Bouaouene) }\end{array}$ & $\begin{array}{l}\text { Fresh aerial parts } \\
\qquad(0.39 \%)\end{array}$ & $\begin{array}{l}\text { 2-Undecanone }(51.2 \%), 2 \text {-nonanone }(39.2 \%) \text {, } \\
\text { and } 2 \text {-decanone }(2.3 \%)\end{array}$ & [45] \\
\hline & $\begin{array}{l}\text { Tunisia } \\
\text { (El Ala) }\end{array}$ & $\begin{array}{l}\text { Air-dried aerial parts } \\
\text { of wild plants }(0.56 \%)\end{array}$ & $\begin{array}{l}\text { 2-Nonanone (37.4\%), 2-undecanone }(20.5 \%), \\
\text { and 2-methyl-octyl acetate }(19.0 \%)\end{array}$ & {$[46]$} \\
\hline & $\begin{array}{l}\text { Tunisia } \\
\text { (Tunisi) }\end{array}$ & $\begin{array}{l}\text { Air-dried parts of } \\
\text { cultivated plants } \\
\qquad(0.60 \%)\end{array}$ & $\begin{array}{l}\text { 2-Undecanone }(39.3 \%), 2 \text {-nonanone }(20.5 \%), \\
\text { and 2-methyl-octyl acetate }(7.6 \%)\end{array}$ & [46] \\
\hline & Turkey & $\begin{array}{l}\text { Fresh aerial parts } \\
\qquad(1.10 \%)\end{array}$ & $\begin{array}{c}\text { 2-Undecanone }(43.2 \%), 2 \text {-nonanone }(27.9 \%), \\
\text { and 2-nonyl acetate }(10.6 \%)\end{array}$ & [47] \\
\hline
\end{tabular}


Table 1. Cont.

\begin{tabular}{|c|c|c|c|c|}
\hline Ruta Species & $\begin{array}{l}\text { Geographical } \\
\text { Sources (Region) }\end{array}$ & Plant Parts (Yield) & Major Components & References \\
\hline \multirow[t]{3}{*}{$\begin{array}{l}\text { Ruta chalepensis } \\
\text { subsp. angustifolia } \\
\text { (Pers.) P. Cout. }\end{array}$} & Algeria & $\begin{array}{l}\text { Shade-dried aerial } \\
\text { parts }(0.91 \%)\end{array}$ & 2-Undecanone $(84.7 \%)$ & [15] \\
\hline & $\begin{array}{l}\text { Algeria } \\
\text { (Jijel) }\end{array}$ & $\begin{array}{l}\text { Fresh aerial parts } \\
\qquad(0.80 \%)\end{array}$ & $\begin{array}{c}\text { 2-Undecanone }(83.4 \%) \text {, carvacrol }(4.1 \%), \\
\text { and 2-nonanone }(4.0 \%)\end{array}$ & {$[48]$} \\
\hline & $\begin{array}{c}\text { Algeria } \\
\text { (Boudouaou) }\end{array}$ & $\begin{array}{l}\text { Air-dried aerial parts } \\
\qquad(0.27 \%)\end{array}$ & $\begin{array}{c}\text { 2-Undecanone }(28.2 \%), \text { 2-nonanone }(20.0 \%), \\
\text { 2-methyloctyl acetate }(12.7 \%) \text {, and } \\
\text { 2-methyldecyl acetate }(5.8 \%)\end{array}$ & [49] \\
\hline $\begin{array}{l}\text { Ruta chalepensis var. } \\
\text { bracteosa (DC) Boiss. }\end{array}$ & $\begin{array}{c}\text { Algeria } \\
\text { (Ain Temouchent) }\end{array}$ & $\begin{array}{l}\text { Air-dried aerial parts } \\
\qquad(0.90 \%)\end{array}$ & $\begin{array}{c}\text { 2-Nonanone }(32.8 \%), \text { 2-undecanone }(32.6 \%), \\
\text { 1-nonene }(14.0 \%), \alpha \text {-limonene }(5.3 \%) \text {, and } \\
\text { 2-decanone }(2.4 \%)\end{array}$ & [18] \\
\hline $\begin{array}{l}\text { Ruta chalepensis } \\
\text { subsp. latifolia } \\
\text { (Salisb.) Linds. }\end{array}$ & Algeria & $\begin{array}{l}\text { Shade-dried aerial } \\
\text { parts }(0.69 \%)\end{array}$ & $\begin{array}{l}\text { 2-Undecanone }(51.2 \%), 2 \text {-nonanone }(20.1 \%) \text {, } \\
\text { 2-octyl-methyl acetate }(15.1 \%) \text {, and 2-dectyl } \\
\text { acetate }(3.3 \%)\end{array}$ & [15] \\
\hline \multirow[t]{15}{*}{ Ruta graveolens L. } & $\begin{array}{l}\text { Algeria } \\
\text { (Anaba) }\end{array}$ & $\begin{array}{l}\text { Air-dried aerial parts } \\
\qquad(0.18 \%)\end{array}$ & $\begin{array}{l}\text { 2-Undecanone }(55.4 \%), 2 \text {-nonanone }(21.6 \%), \\
\text { 1-nonene }(4.4 \%) \text {, and } \alpha \text {-limonene }(4.3 \%)\end{array}$ & [18] \\
\hline & $\begin{array}{c}\text { Brazil } \\
\text { (Maranhão) }\end{array}$ & Fresh leaves $(1.29 \%)$ & $\begin{array}{l}\text { 2-Undecanone }(47.2 \%), 2 \text {-nonanone }(39.2 \%) \text {, } \\
\text { octyl acetate }(7.3 \%) \text {, and 2-decanone }(2.0 \%)\end{array}$ & {$[50]$} \\
\hline & $\begin{array}{c}\text { Brazil } \\
\text { (Ceara) }\end{array}$ & $\begin{array}{l}\text { Fresh leaves } \\
(0.10-0.90 \%)\end{array}$ & $\begin{array}{l}\text { 2-Undecanone }(37.0-58.2 \%) \text { and } \\
\text { 2-nonanone }(17.6-53.1 \%)\end{array}$ & {$[51]$} \\
\hline & Bulgaria & $\begin{array}{l}\text { Shade-dried fruits } \\
\qquad(0.12 \%)\end{array}$ & $\begin{array}{c}\text { 2-Nonanone }(60.1 \%) \text {, benzaldehyde }(7.4 \%) \text {, } \\
\text { and } 2 \text {-undecanone }(7.0 \%)\end{array}$ & [52] \\
\hline & China & $\begin{array}{l}\text { Air-dried aerial parts } \\
(0.99 \%)\end{array}$ & $\begin{array}{l}\text { 2-Undecanol acetate }(19.2 \%) \text { and } \\
\text { 2-undecanol 2-methylbutyl ester }(8.9 \%)\end{array}$ & [8] \\
\hline & $\begin{array}{l}\text { Colombia } \\
\text { (Santander) }\end{array}$ & $\begin{array}{l}\text { Shade-dried aerial } \\
\text { parts }(1.60 \%)\end{array}$ & $\begin{array}{c}\text { 2-Nonanone (35.4\%), 2-undecanone }(30.5 \%) \text {, } \\
\text { and 2-decanone }(3.4 \%)\end{array}$ & [53] \\
\hline & Egypt & $\begin{array}{l}\text { Air-dried leaves } \\
\qquad(0.34 \%)\end{array}$ & $\begin{array}{l}\text { 2-Undecanone }(62.0 \%) \text { and 2-nonanone } \\
\qquad(18.0 \%)\end{array}$ & {$[54]$} \\
\hline & $\begin{array}{l}\text { Egypt } \\
\text { (Minia) }\end{array}$ & $\begin{array}{l}\text { Fresh flowers } \\
\quad(0.215 \%)\end{array}$ & $\begin{array}{l}\text { 2-Undecanone (70.2-84.6\%) and 2-noanone } \\
\qquad(3.0-7.4 \%)\end{array}$ & [55] \\
\hline & & Fresh leaves $(0.37 \%)$ & $\begin{array}{l}\text { 2-Undecanone (52.5-58.1\%) and 2-noanone } \\
\qquad(18.0-25.1 \%)\end{array}$ & [55] \\
\hline & $\begin{array}{l}\text { India } \\
\text { (Rayalaseema } \\
\text { region) }\end{array}$ & $\begin{array}{l}\text { Air-dried aerial parts } \\
\qquad(1.29 \%)\end{array}$ & $\begin{array}{l}\text { 2-Undecaone }(43.7 \%), \text { 2-nonanone }(16.1 \%) \text {, } \\
\text { 2-tridecanone }(2.6 \%) \text {, and 2-decanone }(2.6 \%)\end{array}$ & [56] \\
\hline & $\begin{array}{l}\text { India } \\
\text { (Orissa) }\end{array}$ & $\begin{array}{l}\text { Fresh leaves (field } \\
\text { grown, } 0.80 \% \text { ) }\end{array}$ & $\begin{array}{c}\text { 2-Undecanone }(45.4 \%), 2 \text {-nonanone }(21.4 \%), \\
\text { 2-nonyl acetate }(6.8 \%) \text {, and 2-dodecanone } \\
(4.1 \%)\end{array}$ & [57] \\
\hline & & $\begin{array}{c}\text { Fresh leaves } \\
\text { (micropropagated, } \\
0.84 \% \text { ) }\end{array}$ & $\begin{array}{c}\text { 2-Undecanone }(48.1 \%), 2 \text {-nonanone }(22.5 \%), \\
\text { 2-nonyl acetate }(6.8 \%) \text {, and 2-dodecanone } \\
(4.0 \%)\end{array}$ & [57] \\
\hline & Italy & Commercial oil & $\begin{array}{l}\text { 2-Undecanone }(83.2 \%) \text { and carvacrol } \\
\qquad(15.0 \%)\end{array}$ & [58] \\
\hline & Korea & $\begin{array}{l}\text { Air-dried aerial parts } \\
\qquad(0.06 \%)\end{array}$ & $\begin{array}{c}\text { 2-Isopropyl-5-methylphenol (31\%), } \\
\text { Pentadecanol (18.5\%), 1-methyltridecyl } \\
\text { pentanoate (12.1\%), 4-hexadecanyl pivalate } \\
(6.1 \%), \text { and 2-acetoxytridecane }(5.6 \%)\end{array}$ & [59] \\
\hline & Peru & $\begin{array}{l}\text { Fresh aerial parts } \\
\qquad(0.27 \%)\end{array}$ & $\begin{array}{c}\text { 2-Undecanone (40.9\%), 2-nonanone }(29.0 \%), \\
\text { and } \beta \text {-caryophyllene }(3.4 \%)\end{array}$ & [14] \\
\hline
\end{tabular}


Table 1. Cont.

\begin{tabular}{|c|c|c|c|c|}
\hline \multirow[t]{12}{*}{ Ruta Species } & $\begin{array}{l}\text { Geographical } \\
\text { Sources (Region) }\end{array}$ & Plant Parts (Yield) & Major Components & References \\
\hline & Portugal & $\begin{array}{l}\text { Air-dried aerial parts } \\
\qquad(0.81 \%)\end{array}$ & $\begin{array}{l}\text { 2-Undecanone }(91.0 \%) \text { and } \\
\text { 8-phenyl-2-octanone }(7.0 \%)\end{array}$ & [60] \\
\hline & Russia & $\begin{array}{l}\text { Genetically } \\
\text { transformed fresh } \\
\text { roots }(0.23 \%)\end{array}$ & Geijerene (67.0\%) & [16] \\
\hline & $\begin{array}{c}\text { Tunisia } \\
\text { (Tozeur oases) }\end{array}$ & $\begin{array}{l}\text { Air-dried leaves } \\
\quad(0.21 \%)\end{array}$ & $\begin{array}{l}\text { 1-Nonene }(19.4 \%), \text {-undecanone }(16.2 \%), \\
\text { and } 2 \text {-nonanone }(11.9 \%)\end{array}$ & [61] \\
\hline & $\begin{array}{l}\text { Tunisia } \\
\text { (Tunis) }\end{array}$ & $\begin{array}{c}\text { Fresh aerial parts } \\
(1.67 \%)\end{array}$ & $\begin{array}{l}\text { 2-Undecanone (56.9\%), 2-nonanone }(23.6 \%), \\
\text { and 1-nonen }(4.4 \%)\end{array}$ & {$[62]$} \\
\hline & $\begin{array}{l}\text { Tunisia } \\
\text { (Bizerta) }\end{array}$ & $\begin{array}{l}\text { Oven-dried } \\
\left(40-60{ }^{\circ} \mathrm{C}\right) \text { flowers } \\
(0.25-0.43 \%)\end{array}$ & $\begin{array}{c}\text { 2-Undecanone (22.0-31.0\%), 2-nonanone } \\
(10.5-12.3 \%), 2 \text {-dodecanone (9.8-12.3\%), } \\
\text { 2-tridecanone (10.3-11.7\%), and limonene } \\
(5.4-8.3 \%)\end{array}$ & [63] \\
\hline & & $\begin{array}{l}\text { Oven-dried } \\
\left(40-60{ }^{\circ} \mathrm{C}\right) \text { leaves } \\
(0.57-0.78 \%)\end{array}$ & $\begin{array}{c}\text { 2-Undecanone (26.8-37.3\%), 2-nonanone } \\
\text { (10.5-12.8\%), 2-dodecanone (3.2-5.7\%), } \\
\text { 2-tridecanone (5.1-5.3\%), and limonene } \\
(2.6-5.1 \%)\end{array}$ & [63] \\
\hline & & $\begin{array}{l}\text { Oven-dried } \\
\left(40-60{ }^{\circ} \mathrm{C}\right) \text { stems } \\
(0.42-0.63 \%)\end{array}$ & $\begin{array}{c}\alpha \text {-Eudesmol }(48.8-58.5 \%) \text { and octanoic acid } \\
(28.1-30.5 \%)\end{array}$ & [63] \\
\hline & $\begin{array}{l}\text { Tunisia } \\
\text { (Jemmel) }\end{array}$ & Fresh leaves $(0.30 \%)$ & $\begin{array}{l}\text { 2-Nonanone (38.7\%), 2-undecanone }(27.3 \%) \text {, } \\
\text { and 2-nonanol }(12.3 \%)\end{array}$ & [64] \\
\hline & & Fresh stems $(0.10 \%)$ & $\begin{array}{l}\text { 2-Undecanone }(40.3 \%), 2 \text {-nonanone }(35.0 \%) \text {, } \\
\text { and 2-nonanol }(3.8 \%)\end{array}$ & {$[64]$} \\
\hline & $\begin{array}{l}\text { Tunisia } \\
\text { (Tunis) }\end{array}$ & $\begin{array}{l}\text { Shade-dried aerial } \\
\text { parts }(0.77 \%)\end{array}$ & $\begin{array}{c}\text { 2-Undecanone }(60.6 \%) \text {, borneol }(12.0 \%) \text {, } \\
\text { 2-dodecanol (7.9\%), 2-nonanone }(4.9 \%) \text {, and } \\
\text { 2-dodecanone }(3.7 \%)\end{array}$ & {$[65]$} \\
\hline & Turkey & $\begin{array}{l}\text { Flowers and leaves } \\
\qquad(1.25 \%)\end{array}$ & $\begin{array}{l}\text { 2-Undecanone }(64.8 \%) \text { and 2-nonanone } \\
(13.8 \%)\end{array}$ & [66] \\
\hline \multirow[t]{7}{*}{ Ruta montana $\mathrm{L}$. } & $\begin{array}{c}\text { Algeria } \\
\text { (Blida, Bouira, } \\
\text { Boumerdes, Djelfa, } \\
\text { M'sila, Tipaza and } \\
\text { Tizi ouzou) }\end{array}$ & $\begin{array}{l}\text { Shade-dried aerial } \\
\text { parts }(0.38-1.45 \%)\end{array}$ & $\begin{array}{c}\text { 2-Undecanone }(27.2-81.7 \%), 2 \text {-nonanone } \\
(1.9-39.5 \%), \text { and 2-nonanyl acetate } \\
\text { (trace-24.8\%) }\end{array}$ & [67] \\
\hline & Algeria & $\begin{array}{l}\text { Shade-dried aerial } \\
\text { parts }(0.65 \%)\end{array}$ & $\begin{array}{l}\text { 2-Undecanone }(20.9-70.1 \%), \\
\text { E-caryophyllene }(5.0-9.1 \%), \text { and } \\
\text { caryophyllene oxide }(2.5-3.6 \%)\end{array}$ & [15] \\
\hline & $\begin{array}{l}\text { Algeria } \\
\text { (Tipaza) }\end{array}$ & $\begin{array}{l}\text { Fresh aerial parts } \\
\qquad(0.97 \%)\end{array}$ & $\begin{array}{c}\text { 2-Undecanone }(67.0 \%), \text { 2-decanone }(9.0 \%), \\
\text { and 2-dodecanone }(4.0 \%)\end{array}$ & [68] \\
\hline & & $\begin{array}{l}\text { Air-dried aerial parts } \\
\qquad(0.60 \%)\end{array}$ & $\begin{array}{l}\text { 2-Undecanone }(67.4 \%), 2 \text {-decanone }(7.6 \%), \\
\text { and 2-dodecanone }(4.0 \%)\end{array}$ & [68] \\
\hline & $\begin{array}{l}\text { Algeria } \\
\text { (Oran) }\end{array}$ & $\begin{array}{l}\text { Air-dried aerial parts } \\
\qquad(1.63 \%)\end{array}$ & $\begin{array}{c}\text { 2-Undecanone }(32.8 \%), 2 \text {-nonanone }(29.5 \%), \\
\text { nonanol-2-acetate }(18.2 \%) \text {, and psoralen } \\
(3.5 \%)\end{array}$ & [69] \\
\hline & $\begin{array}{l}\text { Algeria } \\
\text { (Hammam } \\
\text { Melouane) }\end{array}$ & $\begin{array}{l}\text { Shade-dried aerial } \\
\text { parts }(1.80 \%)\end{array}$ & $\begin{array}{c}\text { 2-Undecanone (71.4\%), 2-tridecanone } \\
(10.5 \%), 2 \text {-dodecanone }(8.1 \%), \text { and } \\
\text { 2-decanone }(5.4 \%)\end{array}$ & [70] \\
\hline & $\begin{array}{c}\text { Morocco } \\
\text { (Boulemane region) }\end{array}$ & $\begin{array}{c}\text { Air-dried aerial parts } \\
(1.46 \%)\end{array}$ & $\begin{array}{c}\text { 2-Undecanone }(82.6 \%), \text { 2-undecanol }(2.9 \%) \\
\text { and 2-undecanol acetate }(2.1 \%)\end{array}$ & [71] \\
\hline
\end{tabular}


Table 1. Cont.

\begin{tabular}{|c|c|c|c|c|}
\hline Ruta Species & $\begin{array}{c}\text { Geographical } \\
\text { Sources (Region) }\end{array}$ & Plant Parts (Yield) & Major Components & References \\
\hline & $\begin{array}{l}\text { Morocco } \\
\text { (Taza) }\end{array}$ & $\begin{array}{l}\text { Air-dried aerial parts } \\
\qquad(0.37 \%)\end{array}$ & $\begin{array}{l}\text { 2-Undecanone }(64.9 \%) \text {, camphor }(3.8 \%) \text {, and } \\
\text { cyclopropane carboxylic acid }(3.7 \%)\end{array}$ & [72] \\
\hline & $\begin{array}{l}\text { Tunisia } \\
\text { (Tunis) }\end{array}$ & $\begin{array}{l}\text { Fresh aerial parts } \\
\qquad(1.21 \%)\end{array}$ & $\begin{array}{c}\text { 2-Undecanone }(88.8 \%) \text { and 2-decanone } \\
(4.9 \%)\end{array}$ & {$[62]$} \\
\hline & $\begin{array}{l}\text { Tunisia } \\
\text { (Sfax) }\end{array}$ & $\begin{array}{l}\text { Air-dried leaves } \\
\qquad(0.26 \%)\end{array}$ & $\begin{array}{l}\text { 1-Butene }(38.3 \%), 2 \text {-butene }(22.6 \% \text {, } \\
\text { methylcyclopropane }(15.5 \%) \text {, and } \\
\text { caryophyllene oxide }(8.2 \%)\end{array}$ & [73] \\
\hline & \multirow[t]{2}{*}{ Tunisia (Joumine) } & $\begin{array}{l}\text { Air-dried leaves } \\
\qquad(0.66 \%)\end{array}$ & $\begin{array}{c}\text { 2-Undeconone }(52.2 \%), \text { 1-nonene }(13.5 \%) \\
\text { 2-nonanone }(10.1 \%), \text { and } 2 \text {-undecanol } \\
(2.4 \%)\end{array}$ & [41] \\
\hline & & $\begin{array}{l}\text { Air-dried stems } \\
\qquad(0.66 \%)\end{array}$ & $\begin{array}{l}\text { 2-Undeconone }(44.9 \%), 1 \text {-nonene }(5.8 \%) \text { and } \\
\text { 2-nonanone }(3.9 \%)\end{array}$ & [41] \\
\hline $\begin{array}{l}\text { Ruta tuberculata } \\
\text { Forssk. }\end{array}$ & $\begin{array}{l}\text { Algeria } \\
\text { (Bechar) }\end{array}$ & $\begin{array}{l}\text { Air-dried aerial parts } \\
\qquad(0.11 \%)\end{array}$ & $\begin{array}{l}\text { Piperitone }(13.6 \%) \text {, trans- } p \text {-menth-2-en-1-ol } \\
(13.1 \%) \text {, cis-piperitol }(12.3 \%), \\
\text { cis-p-menth-2-en-1-ol }(13.1 \%), \text { trans-piperitol } \\
(4.1 \%) \text {, and } 2 \text {-undecanone }(1.6 \%)\end{array}$ & [18] \\
\hline
\end{tabular}

\section{Bioactivities}

Essential oils are well-known for their bioactivities, e.g., antimicrobial and antioxidant, and have long been used in different traditional medicine systems as well as in modern medicine, cosmetics, and pharmaceutical products [29,74-92]. Their applications as an insecticidal, larvicidal, nematocidal, pesticidal, phytotoxic, and insect-repellent agents are also well-documented [93-116]. Ruta essential oils found their way into various traditional medicinal products, and a significant body of literature could establish their bioactivities and medicinal potential [4]. Major bioactivities of Ruta essential oils include anti-inflammatory, antimicrobial, antioxidant, antiprotozoal, cytotoxic, herbicidal, insecticidal, insect repellent, larvicidal, nematocidal/anthelmintic, and phytotoxic activities. Significant differences in potencies in bioactivities do exist among different $R u t a$ species because of the variations in the chemical composition of the essential oils arising from Ruta species being collected from different geographical sources, at different collection times, and from different plant parts, e.g., leaves, stems, flowers, fruits, and roots. The following subsections capture these bioactivities with specific examples.

\subsection{Antimicrobial Activity}

Plant essential oils, e.g., tea tree, rosemary, and lavender oils, have long been known for their antimicrobial properties [77]. The antimicrobial properties of Ruta essential oils are also known [4]. Ruta essential oils, aliphatic ketones being the major components, have been reported to possess weak to moderate levels of antibacterial and antifungal properties compared to standard antibiotics $[4,78,79]$. By virtue of these properties, Ruta essential oils and their components, e.g., 2-undecanone, 2-undecanol, and their derivatives, have been used in various antimicrobial traditional medicine preparations, and in the prevention of decay of fruits and vegetables to enhance their shelf-life.

Most of the in vitro antimicrobial studies reported to date on Ruta essential oils were performed with total essential oils and using the classical agar disc diffusion assay or microdilution assay. However, the most abundant compound of the Ruta essential oils, 2-undecanone (Figure 2), and its derivatives were tested for their antimicrobial property against two bacterial species, namely, Bacillus subtilis and Escherichia coli, and two fungal species, Aspergillus niger (mold) and Candida mycoderma (yeast) using the impedimetric method [80]. 2-Undecanone showed a low level (MIC $=>30 \mu \mathrm{L} / \mathrm{mL}$ ) of bacteriostatic activity against both bacterial species but was more active against the fungal species (MIC 
$1 \mu \mathrm{L} / \mathrm{mL}$ ). The antibacterial potency of 2-isopropyl-5-methylphenol (Figure 4), isolated from the essential oil from the aerial parts of $R$. graveolens, and several of its analogs were evaluated against three Gram-positive (Bacillus cereus, Listeria monocytogenes, and Staphylococcus intermedius), and three Gram-negative (Salmonella enterica, Salmonella typhimurium, and Shigella sonnei) bacterial species [59], and 2-isopropyl-5-methylphenol (Figure 4) showed significant antibacterial activity (zones of inhibition 18-20 mm) against all six tested bacterial species, with the positive control tetracycline having zones of inhibition of 20-24 mm. The antibacterial and antifungal activities of Ruta essential oils are described with specific examples in the following subsections.<smiles>Cc1ccc(C(C)C)c(O)c1</smiles>

Figure 4. Structure of 2-isopropyl-5-methylphenol.

\subsubsection{Antibacterial Activity}

Ruta essential oils, mainly from $R$. chalepensis, $R$. graveolens, and $R$. montana, have been shown to possess low to moderate levels of antibacterial activity against both Grampositive and Gram-negative bacteria [4,79] (Table 2). In most of the antibacterial screenings of Ruta essential oils, a standard mix of 10-12 Gram-positive and Gram-negative human pathogenic bacterial species from the genera Bacillus, Citrobacter, Enterococcus, Escherichia, Klebsiella, Listeria, Proteus, Pseudomonas, Salmonella, and Staphylococcus was used. In some studies, however, plant pathogenic bacterial species like Clavibacter michiganensis subsp. michiganensis and Xanthomonas albilineans were used [23]. The levels of activities among the essential oils from the genus Ruta were found to vary significantly, both in potency and susceptibility (Table 2). No preferential or selective antibacterial activity could be observed between Gram-positive and Gram-negative groups. Antibacterial activities reported in the literature are from routine assays and are of a preliminary nature, without any reasonable efforts towards establishing the plausible mechanisms of action or identifying components responsible for the activity.

The essential oil obtained from the aerial parts of $R$. angustifolia was found to be inactive against most of the tested organisms but was active against Bacillus cereus (10 $\mathrm{mm})$, Enterococcus faecalis (8 $\mathrm{mm})$, and Citrobacter freundii $(7 \mathrm{~mm})$ [18]. It should be mentioned that the disc diameter was $6 \mathrm{~mm}$, and any activity mentioned with a zone of inhibition of $6 \mathrm{~mm}$ should be considered inactive. The antibacterial activity reported for $R$. chalepensis essential oil was mostly associated with the essential oils obtained from its whole aerial parts and leaves (Table 2). The only report on the antibacterial activity of its root essential oil was observed against Listeria monocytogenes and Pseudomonas aeruginosa [17], while that of the essential oil from its stem was tested against Escherichia coli, Listeria monocytogenes, Pseudomonas aeruginosa, Salmonella typhi, and Staphylococcus aureus [17]. This study [17] demonstrated that a significant difference could exist between the antibacterial profiles of Ruta essential oils obtained from two different organs of the same plant and that they can have different chemical properties. The essential oil from the aerial parts of $R$. chalepensis L. var. bracteosa was active against Acinetobacter baumanii (12 mm), Bacillus cereus (12 mm), Enterococcus faecalis (10 $\mathrm{mm})$, Citrobacter freundii $(7 \mathrm{~mm})$, Escherichia coli $(7 \mathrm{~mm})$, Proteus mirabilis (10 mm), Salmonella typhi (15 mm), and Staphylococcus aureus (17 $\mathrm{mm})$, while no activity was observed against Citrobacter freundii, Enterobacter cloacae, Klebsiella pneumoniae, Listeria monocytogenes, and Pseudomonas aeruginosa [18]. 
Like $R$. chalepensis, the essential oils obtained from the whole aerial parts and leaves of $R$. graveolens have mainly been explored for their potential antibacterial activity (Table 2). The study conducted by Owlia et al. [82] could not find any detectable activity of the essential oil from the aerial parts of $R$. graveolens against Pseudomonas aeruginosa. Reddy et al. [56] reported a moderate level of activity with a zone of inhibition of $15 \mathrm{~mm}$ against this species. In fact, the work carried out by Reddy et al. [56] with the essential oils from the aerial parts of $R$. graveolens is one of the most extensive in vitro antibacterial activity assessments to date, and this study revealed activity against a range of bacterial species, e.g., Acinetobacter baumannii (19 mm), Bacillus cereus (28 mm), Citrobacter freundii (16 $\mathrm{mm})$, Enterobacter aerogenes $(13 \mathrm{~mm})$, Enterobacter cloacae $(18 \mathrm{~mm})$, Enterococcus faecalis (27 $\mathrm{mm})$, Escherichia coli $(18 \mathrm{~mm})$, Klebsiella pneumoniae $(18 \mathrm{~mm})$, Listeria monocytogenes (18 mm), Micrococcus flavus (21 mm), Micrococcus luteus (19 mm), Proteus mirabilis (22 mm), Pseudomonas aeruginosa (15 $\mathrm{mm})$, Salmonella typhimurium $(13 \mathrm{~mm})$, and Staphylococcus aureus $(23 \mathrm{~mm})$. They not only reported the zones of inhibition against the tested bacterial species, but also worked out the MIC values $(0.65-1.58 \mu \mathrm{g} / \mathrm{mL}$ in most cases) (Table 2). While the anti-Helicobacter pylori activity of this essential oil was reported in one study [83], the activity against Legionella pneumophila (MIC $<0.02-0.40 \mu \mathrm{g} / \mathrm{mL}$ ) was only reported by Chaftar et al. [65]. In addition to activity against human pathogenic bacterial species, Mahmoud et al. [54], assessed the antibacterial property of the essential oil from the leaves of $R$. graveolens against plant pathogenic bacterial species Dickeya solani $(420 \mu \mathrm{g} / \mathrm{mL})$, Pectobacterium atrosepticum $(310 \mu \mathrm{g} / \mathrm{mL})$, and Pectobacterium carotovorum subsp. carotovorum $(110 \mu \mathrm{g} / \mathrm{mL})$. It can be noted that the bacterial genus Pectobacterium comprises several enterobacterial species that produce plant diseases, e.g., soft rot, wilt, and blackening in potato and ornamental plants. Similarly, Dickeya solani is also a causative bacterial species for soft rot and blackening of potato crops.

The essential oils from the whole aerial parts and leaves of $R$. motana have also been found to possess antibacterial properties (Table 2). Drioiche et al. [71] conducted probably the most elaborate antibacterial study on the essential oil of the aerial parts of this Ruta species, and found low-moderate levels of activity against, Citrobacter koseri $(8 \mathrm{~mm})$, Corynebacterium sp. (11 $\mathrm{mm})$, Enterococcus faecalis $(7 \mathrm{~mm})$, Enterococcus faecium $(17 \mathrm{~mm})$, Escherichia coli $(8 \mathrm{~mm})$, Klebsiella oxytoca $(8 \mathrm{~mm})$, Listeria sp. (11 $\mathrm{mm})$, Proteus mirabilis $(7 \mathrm{~mm})$, Pseudomonas aeruginosa $(8 \mathrm{~mm})$, Salmonella sp. (11 $\mathrm{mm})$, Serratia marcescens $(8 \mathrm{~mm})$, Staphylococcus aureus $(8 \mathrm{~mm})$, Staphylococcus haemolyticus $(8 \mathrm{~mm})$, Streptococcus acidominimus (7 $\mathrm{mm})$, Streptococcus porcinus $(8 \mathrm{~mm})$, and Yersinia enterolitica $(8 \mathrm{~mm})$, but no activity was reported against Enterobacter aerogens, Enterobacter cloacae, Klebsiella pneumonie ssp. Pneumonie, Pseudomonas fluorescence, Pseudomonas putida, Shigella sp., Staphylococcus epidermidis, Streptococcus agalactiae, and Streptococcus groupe. In another study, the essential oil of the aerial parts was found to be inactive against Escherichia coli but showed significant activity against Staphylococcus aureus with a zone of inhibition of $18 \mathrm{~mm}$ [70].

The only report on the antibacterial activity of the essential oil from the aerial parts of R. tuberculata revealed activity against Bacillus cereus, Enterococcus faecalis, Salmonella typhi, and Staphylococcus aureus with zones of inhibition between 8 and $14 \mathrm{~mm}$ (Table 2), but no activity was observed against Acinetobacter baumanii, Citrobacter freundii, Enterobacter cloacae, Escherichia coli, Klebsiella pneumoniae, Listeria monocytogenes, Proteus mirabilis, or Pseudomonas aeruginosa [18]. 
Table 2. Antibacterial activity of Ruta essential oils.

Ruta Essential Oil Source Aerial parts
Activity against Bacterial Species (Zones of Inhibition in $\mathrm{mm}$ and/or MIC in $\mu \mathrm{g} / \mathrm{mL}$ )

No detectable activity against Acinetobacter baumanii, Enterobacter cloacae, Escherichia coli, Klebsiella pneumoniae, Listeria monocytogenes,

Proteus mirabilis, Pseudomonas aeruginosa, Salmonella typhi, and Staphylococcus aureus

Active against Bacillus cereus (10 mm), Enterococcus faecalis ( $8 \mathrm{~mm})$, and Citrobacter freundii $(7 \mathrm{~mm})$

Ruta chalepensis L. Aerial parts

Ruta chalepensis L. Aerial parts

Ruta chalepensis L. Aerial parts

Ruta chalepensis L. Leaves

Ruta chalepensis L. Leaves

Ruta chalepensis L. Leaves

Ruta chalepensis L. Leaves

Ruta chalepensis L. Leaves and stems

Ruta chalepensis L. Roots

Ruta chalepensis L. Stems

Ruta chalepensis L. var. bracteosa Aerial parts

Plant pathogenic bacterial species, Clavibacter michiganensis subsp. michiganensis and Xanthomonas albilineans

Streptococcus suis

Bacillus subtilis (24 mm), Escherichia coli (22 mm), Klebsiella pneumoniae (25 $\mathrm{mm})$, and Staphylococcus aureus (24 $\mathrm{mm})$

No detectable activity against Aeromonas hydrophila, Bacillus subtilis, Escherichia coli, Listeria monocytogenes, Pseudomonas aeruginosa, Salmonella typhimurium, and Staphylococcus aureus

Escherichia coli, Listeria monocytogenes, and Pseudomonas aeruginosa

Escherichia coli $(750 \mu \mathrm{g} / \mathrm{mL})$, Pseudomonas aeruginosa $(7000 \mu \mathrm{g} / \mathrm{mL})$, Staphylococcus aureus $(2500 \mu \mathrm{g} / \mathrm{mL})$ and methicillin resistant Staphylococcus aureus (MRSA) $(4000 \mu \mathrm{g} / \mathrm{mL})$

Escherichia coli $(15.6 \mu \mathrm{g} / \mathrm{mL})$, Pseudomonas aeruginosa $(125 \mu \mathrm{g} / \mathrm{mL})$ and Staphylococcus aureus $15.6 \mu \mathrm{g} / \mathrm{mL}$ )

Escherichia coli $(>512 \mu \mathrm{g} / \mathrm{mL})$ and Staphylococcus aureus $(>512 \mu \mathrm{g} / \mathrm{mL})$

Listeria monocytogenes and Pseudomonas aeruginosa

Escherichia coli, Listeria monocytogenes, Pseudomonas aeruginosa,

No detectable activity against Citrobacter freundii, Enterobacter cloacae, Klebsiella pneumoniae, Listeria monocytogenes, and Pseudomonas aeruginosa

Active against Acinetobacter baumanii (12 mm), Bacillus cereus

9]
Salmonella typhi, and Staphylococcus aureus (12 mm), Enterococcus faecalis (10 mm), Citrobacter freundii $(7 \mathrm{~mm})$,

Escherichia coli $(7 \mathrm{~mm})$, Proteus mirabilis (10 mm), Salmonella typhi $(15 \mathrm{~mm})$, and Staphylococcus aureus $(17 \mathrm{~mm})$

Ruta graveolens L. Aerial parts

Escherichia coli (7 mm), Klebsiella pneumoniae (no activity), Pseudomonas aeruginosa (12 $\mathrm{mm})$, and Staphylococcus aureus (16 $\mathrm{mm})$

Ruta graveolens L. Aerial parts

No activity against Pseudomonas aeruginosa

Ruta graveolens L. Aerial parts

Helicobacter pylori

Ruta graveolens L. Aerial parts

]


Table 2. Cont.

Activity against Bacterial Species (Zones of Inhibition in $\mathrm{mm}$ and/or MIC in $\mu \mathrm{g} / \mathrm{mL}$ )

\section{Ruta Essential Oil Source}

Ruta graveolens $\mathrm{L}$. Aerial parts
References

Acinetobacter baumannii (19 mm, MIC $1.22 \mu \mathrm{g} / \mathrm{mL}$ ), Bacillus cereus

(28 mm, MIC $1.0 \mu \mathrm{g} / \mathrm{mL})$, Citrobacter freundii (16 mm, MIC

$1.0 \mu \mathrm{g} / \mathrm{mL})$, Enterobacter aerogenes $(13 \mathrm{~mm}$, MIC $72.0 \mu \mathrm{g} / \mathrm{mL})$,

Enterobacter cloacae $(18 \mathrm{~mm}$, MIC $0.89 \mu \mathrm{g} / \mathrm{mL})$, Enterococcus faecalis

(27 mm, MIC $1.0 \mu \mathrm{g} / \mathrm{mL})$, Escherichia coli $(18 \mathrm{~mm}$, MIC $0.65 \mu \mathrm{g} / \mathrm{mL})$,

Klebsiella pneumoniae (18 mm, MIC $1.58 \mu \mathrm{g} / \mathrm{mL})$, Listeria

monocytogenes (18 mm, MIC $0.70 \mu \mathrm{g} / \mathrm{mL}$ ), Micrococcus flavus ( $21 \mathrm{~mm}$,

MIC $1.48 \mu \mathrm{g} / \mathrm{mL})$, Micrococcus luteus (19 mm, MIC $1.0 \mu \mathrm{g} / \mathrm{mL})$,

Proteus mirabilis (22 mm, MIC $0.76 \mu \mathrm{g} / \mathrm{mL})$, Pseudomonas aeruginosa

(15 mm, MIC $1.0 \mu \mathrm{g} / \mathrm{mL})$, Salmonella typhimurium (13 mm, MIC

$1.34 \mu \mathrm{g} / \mathrm{mL}$ ), and Staphylococcus aureus (23 mm, MIC $1.0 \mu \mathrm{g} / \mathrm{mL}$ )

Food-borne bacterial species, Bacillus cereus (15 mm, MIC

$75 \mu \mathrm{g} / \mathrm{mL})$, Listeria monocytogenes (13 mm, MIC $75 \mu \mathrm{g} / \mathrm{mL}$ ),

Salmonella enterica $(22 \mathrm{~mm}$, MIC $25 \mu \mathrm{g} / \mathrm{mL})$, Staphylococcus intermedius (14 mm, MIC $25 \mu \mathrm{g} / \mathrm{mL})$, Shigella sonnei $(14 \mathrm{~mm}$, MIC

$25 \mu \mathrm{g} / \mathrm{mL})$, and Salmonella typhimurium (15 mm, MIC $25 \mu \mathrm{g} / \mathrm{mL})$

No detectable activity against Acinetobacter baumanii, Citrobacter

freundii, Enterobacter cloacae, Klebsiella pneumoniae, Listeria monocytogenes, and Pseudomonas aeruginosa

Ruta graveolens L. Aerial parts

Active against Bacillus cereus (12 mm), Enterococcus faecalis (9 mm),

Escherichia coli $(7 \mathrm{~mm})$, Proteus mirabilis $(7 \mathrm{~mm})$, Salmonella typhi $(12 \mathrm{~mm})$, and Staphylococcus aureus $(12 \mathrm{~mm})$

Bacillus cereus ( $26 \mathrm{~mm}$, MIC $1.0 \mu \mathrm{g} / \mathrm{mL})$, Enterobacter aerogenes

(13 mm, MIC $1.4 \mu \mathrm{g} / \mathrm{mL})$, Escherichia coli (18 mm, MIC $1 \mu \mathrm{g} / \mathrm{mL})$,

Ruta graveolens L. Leaves

Micrococcus flavus (19 mm, MIC $0.75 \mu \mathrm{g} / \mathrm{mL})$, Micrococcus luteus

(17 mm, MIC $0.89 \mu \mathrm{g} / \mathrm{mL})$, Pseudomonas aeruginosa ( $8.0 \mathrm{~mm}$, MIC

$75.0 \mu \mathrm{g} / \mathrm{mL})$, Salmonella typhi (12 mm, MIC $1.0 \mu \mathrm{g} / \mathrm{mL})$, and Staphylococcus aureus (22 mm, MIC $1.0 \mu \mathrm{g} / \mathrm{mL}$ )

Bacillus cereus $(210 \mu \mathrm{g} / \mathrm{mL})$, Dickeya solani $(420 \mu \mathrm{g} / \mathrm{mL})$ Escherichia coli $(100 \mu \mathrm{g} / \mathrm{mL})$, Listeria monocytogenes $(210 \mu \mathrm{g} / \mathrm{mL})$, Micrococcus flavus $(210 \mu \mathrm{g} / \mathrm{mL})$, Pectobacterium atrosepticum $(310 \mu \mathrm{g} / \mathrm{mL})$,

Pectobacterium carotovorum subsp. carotovorum $(110 \mu \mathrm{g} / \mathrm{mL})$,

Pseudomonas aeruginosa ( $350 \mu \mathrm{g} / \mathrm{mL})$, and Staphylococcus aureus $(100 \mu \mathrm{g} / \mathrm{mL})$

\begin{tabular}{|c|c|c|}
\hline $\begin{array}{l}\text { Ruta graveolens L. } \\
\text { Leaves }\end{array}$ & Staphylococcus aureus $(10-20 \mathrm{~mm})$ & [78] \\
\hline $\begin{array}{l}\text { Ruta graveolens L. } \\
\text { Leaves and flowers }\end{array}$ & $\begin{array}{c}\text { Escherichia coli (MIC 7.5-7.9 } \mu \mathrm{g} / \mathrm{mL}), \text { Klebsiella pneumoniae (MIC } \\
4.5-5.2 \mu \mathrm{g} / \mathrm{mL}), \text { Pseudomonas aeruginosa }(\mathrm{MIC} 5.8-6.3 \mu \mathrm{g} / \mathrm{mL} \text { ), and } \\
\text { Staphylococcus aureus (MIC } 3.5-3.9 \mu \mathrm{g} / \mathrm{mL} \text { ) }\end{array}$ & [55] \\
\hline $\begin{array}{l}\text { Ruta montana L. } \\
\text { Aerial parts }\end{array}$ & $\begin{array}{c}\text { Escherichia coli }(9 \mathrm{~mm}), \text { Klebsiella pneumoniae (no activity), } \\
\text { Pseudomonas aeruginosa }(21 \mathrm{~mm}) \text {, and Staphylococcus aureus }(21 \mathrm{~mm})\end{array}$ & [62] \\
\hline $\begin{array}{l}\text { Ruta montana L. } \\
\text { Aerial parts }\end{array}$ & $\begin{array}{c}\text { Not active against Escherichia coli } \\
\text { Active against Staphylococcus aureus (18 mm) }\end{array}$ & [70] \\
\hline $\begin{array}{l}\text { Ruta montana L. } \\
\text { Aerial parts }\end{array}$ & $\begin{array}{l}\text { Bacillus subtilis }(10-15 \mathrm{~mm}), \text { Enterobacter faceium }(11-13 \mathrm{~mm}) \text {, } \\
\text { Escherichia coli }(10-14 \mathrm{~mm}), \text { Klebsiella pneumoniae }(10-13 \mathrm{~mm}) \text {, } \\
\text { Pseudomonas aeruginosa }(9-13 \mathrm{~mm}) \text {, and Staphylococcus aureus } \\
\qquad(12-16 \mathrm{~mm})\end{array}$ & [67] \\
\hline $\begin{array}{l}\text { Ruta montana L. } \\
\text { Aerial parts }\end{array}$ & $\begin{array}{c}\text { Bacillus subtilis }(21 \mathrm{~mm}, \text { MIC } 6250 \mu \mathrm{g} / \mathrm{mL}) \text {, Escherichia coli (not } \\
\text { active), Listeria innocua }(10 \mathrm{~mm}) \text {, and Proteus mirabilis }(17 \mathrm{~mm} \text {, MIC } \\
6250 \mu \mathrm{g} / \mathrm{mL}), \text { Pseudomonas aeruginosa }(9 \mathrm{~mm}) \text {, and Staphylococcus } \\
\text { aureus }(12 \mathrm{~mm}, \text { MIC }>25000 \mu \mathrm{g} / \mathrm{mL})\end{array}$ & [72] \\
\hline
\end{tabular}


Table 2. Cont.

Ruta Essential Oil Source

Ruta montana L.

Aerial parts
Activity against Bacterial Species (Zones of Inhibition in $\mathrm{mm}$ and/or MIC in $\mu \mathrm{g} / \mathrm{mL}$ )
References

Activity against Citrobacter koseri (8 mm), Corynebacterium sp.

(11 mm), Enterococcus faecalis (7 mm), Enterococcus faecium (17 mm),

Escherichia coli $(8 \mathrm{~mm})$, Klebsiella oxytoca $(8 \mathrm{~mm})$, Listeria sp. $(11 \mathrm{~mm})$,

Proteus mirabilis $(7 \mathrm{~mm})$, Pseudomonas aeruginosa $(8 \mathrm{~mm})$, Salmonella

sp. (11 mm), Serratia marcescens (8 $\mathrm{mm})$, Staphylococcus aureus

(8 $\mathrm{mm})$, Staphylococcus haemolyticus (8 $\mathrm{mm})$, Streptococcus

acidominimus (7 $\mathrm{mm})$, Streptococcus porcinus $(8 \mathrm{~mm})$, and Yersinia

enterolitica $(8 \mathrm{~mm})$. No activity against Enterobacter aerogens,

Enterobacter cloacae, Klebsiella pneumonie ssp. Pneumonie, Pseudomonas

fluorescence, Pseudomonas putida, Shigella sp., Staphylococcus

epidermidis, Streptococcus agalactiae, and Streptococcus groupe

Ruta montana L.

Aerial parts

Agrobacterium tumefaciens

[73]

No detectable activity against Acinetobacter baumanii, Citrobacter

freundii, Enterobacter cloacae, Escherichia coli, Klebsiella pneumoniae,

Ruta tuberculata Forssk. Aerial parts

Listeria monocytogenes, Proteus mirabilis, and Pseudomonas aeruginosa.

Active against Bacillus cereus (12 mm), Enterococcus faecalis (14 mm),

Salmonella typhi $(8 \mathrm{~mm})$, and Staphylococcus aureus $(10 \mathrm{~mm})$

[71]

\subsubsection{Antifungal Activity}

Ruta essential oils were shown to possess significant levels of antifungal activity, fungicidal as well as fungistatic, against several common fungal species, e.g., Alternaria alternata, Aspergillus fumigatus, Aspergillus niger, Candida albicans, and Fusarium oxyxporum (Table 3), and in certain cases, the activity was comparable to or even better than the positive control (known antifungal agents, e.g., amphotericin) $[4,18,84,85]$ (Table 3). The essential oil from the aerial parts of $R$. angustifolia showed the most potent antifungal activity against Candida albicans $(35 \mathrm{~mm})$ and the least activity against Cladosporium herbarum $(18 \mathrm{~mm})$, while that of $R$. chalepensis var. bracteosa was most active against Cladosporium herbarum (35 mm) and the least against Fusarium oxysporum (8 mm) [18]. Ruta essential oils not only demonstrated activity against human pathogenic fungal species, but showed activity against plant pathogenic fungi as well, for example, the essential oil of the aerial parts of $R$. chalepensis appeared to be active against Alternaria sp. [40,86]. Although Alternaria sp. are generally plant pathogens, they are common allergens and cause hay fever and hypersensitivity reactions in humans. Generally, the essential oils of Ruta species, especially $R$. chalepensis, have been found to be effective against various Aspergillus species [17,18,42,87].

The essential oil of the aerial parts of $R$. graveolens exhibited antifungal activity against Melassezia furfur, which is usually found on the human skin and is responsible for skin diseases and dermatological conditions [88]. This essential oil was also active against several Candida species, namely, C. albicans (MIC $8.2 \mu \mathrm{g} / \mathrm{mL}$ ), C. parapsilopsis (MIC $16.4 \mu \mathrm{g} / \mathrm{mL}$ ), C. glabrata (MIC $4.1 \mu \mathrm{g} / \mathrm{mL}$ ), and C. tropicalis (MIC $131.0 \mu \mathrm{g} / \mathrm{mL}$ ) [89], and the plant pathogenic fungi Sclerotinia sclerotiorum (which causes white mold disease in plants) [90], Bipolaris oryzae, and Gerlachia oryzae [91,92].

The major antifungal activity of the essential oil of the aerial part of $R$. montana was against Aspergillus, Alternaria, and Candida species [18,67,70-73,84]. This essential oil was also found to be active against Saccharomyces cerevisiae (12-15 mm) [67]), Cryptococcus neoformans (20 mm), Fusarium sp. (14 mm), Penicillium sp. (15 mm), Rhodotorula rubra (11 $\mathrm{mm})$, Trichophyton mentagrophytes $(15 \mathrm{~mm})$, and Trichosporon sp. (17 $\mathrm{mm})$ [71], as well as Botrytis cinerea, Fusarium oxysporum, Fusarium solani, and Verticillium dahlia with MICs $100-1100 \mu \mathrm{g} / \mathrm{mL}[18,73]$. A summary of the antifungal activities of Ruta essential oils is presented in Table 3. 
Table 3. Antifungal activity of Ruta essential oils.

Activity against Fungal Species (Zones of Inhibition in $\mathrm{mm}$ or MIC in $\mu \mathrm{g} / \mathrm{mL}$ )

\section{Ruta Essential Oil Source}

Ruta angustifolia Pers. Aerial parts

Ruta chalepensis L. var. bracteosa Aerial parts
References

fumigatus $(20 \mathrm{~mm})$, Candida albicans $(35 \mathrm{~mm})$, Cladosporium herbarum

$(18 \mathrm{~mm})$, and Fusarium oxysporum $(20 \mathrm{~mm})$

Alternaria alternaria (10 mm), Aspergillus flavus (16 mm), Aspergillus

fumigatus (23 mm), Candida albicans (15 $\mathrm{mm})$, Cladosporium herbarum (35 $\mathrm{mm})$, and Fusarium oxysporum $(8 \mathrm{~mm})$

Ruta chalepensis L. Aerial parts

Candida albicans $(28 \mathrm{~mm})$ and Saccharomyces cerevisiae $(27 \mathrm{~mm})$

Ruta chalepensis L. Aerial parts

Alternaria sp. (24 mm) and Microdochium nivale $(29 \mathrm{~mm})$

Ruta chalepensis L. Aerial parts

Alternaria solani (22 mm)

Ruta chalepensis L. Leaves

Candida albicans (MIC $2750 \mu \mathrm{g} / \mathrm{mL}$ )

Ruta chalepensis L. Leaves

Aspergillus flavus (17 mm), Aspergillus niger (15 mm), and Candida albicans $(11 \mathrm{~mm})$

Growth inhibition (100\%) of Fusarium culmorum, Fusarium

Ruta chalepensis L. Leaves

graminearum, Fusarium polyphialidicum, Fusarium proliferatum, and

Fusarium pseudograminearum at a concentration of the essential oil at $20 \mu \mathrm{L} / \mathrm{mL}$

Ruta chalepensis L.

Leaves and stems

Candida albicans $(512 \mu \mathrm{g} / \mathrm{mL})$ and Trichophyton rubrum $(512 \mu \mathrm{g} / \mathrm{mL})$

Ruta chalepensis L. Leaves, roots and stems

Aspergillus spp. (26 mm), Saccharomyces cerevisiae (26 mm),

Streptomyces griseus (20 mm), Fusarium solani (19 mm), and Penicillium thomii $(16 \mathrm{~mm})$

Ruta graveolens L. Aerial parts

Aspergillus parasiticus (28 $\mathrm{mm})$

Ruta graveolens L. Aerial parts

Alternaria alternata (22 mm), Aspergillus flavus (26 mm), Aspergillus fumigatus (14 $\mathrm{mm})$, Candida albicans $(35 \mathrm{~mm})$, Cladosporium herbarum $(26 \mathrm{~mm})$, and Fusarium oxysporium $(20 \mathrm{~mm})$

Ruta graveolens L. Aerial parts

Melassezia furfur (30 mm)

Ruta graveolens L. Aerial parts

Candida albicans $(8.2 \mu \mathrm{g} / \mathrm{mL})$, Candida parapsilopsis $(16.4 \mu \mathrm{g} / \mathrm{mL})$, Candida glabrata $(4.1 \mu \mathrm{g} / \mathrm{mL})$, and Candida tropicalis $(131.0 \mu \mathrm{g} / \mathrm{mL})$

Ruta graveolens L. Aerial parts

Alternaria alternaria (25 mm), Aspergillus flavus (22 mm), Aspergillus fumigatus (15 mm), Candida albicans (33 mm), Cladosporium herbarum $(25 \mathrm{~mm})$, and Fusarium oxysporum $(20 \mathrm{~mm})$

Ruta graveolens L. Aerial parts

Sclerotinia sclerotiorum (27 mm)

[90]

Ruta graveolens L. Aerial parts

Ruta graveolens L. Aerial parts

Ruta graveolens L. Leaves

Reduced colony forming unit (CFU) of Bipolaris oryzae and Gerlachia oryzae

Reduced colony forming unit (CFU) of Bipolaris oryzae and Gerlachia oryzae

Monilinia fructicola $(240 \mu \mathrm{g} / \mathrm{mL})$

Ruta graveolens L. Leaves

Candida albicans (15 $\mathrm{mm}$ ) and Candida krusei (17 nm) 
Table 3. Cont.

\begin{tabular}{|c|c|c|}
\hline Ruta Essential Oil Source & $\begin{array}{c}\text { Activity against Fungal Species } \\
\text { (Zones of Inhibition in } \mathrm{mm} \text { or MIC in } \mu \mathrm{g} / \mathrm{mL} \text { ) }\end{array}$ & References \\
\hline $\begin{array}{l}\text { Ruta graveolens L. } \\
\text { Leaves and flowers }\end{array}$ & $\begin{array}{c}\text { Candida albicans (MIC 1.1-2.1 } \mu \mathrm{g} / \mathrm{mL} \text { ), Candida albicans clinical strain } \\
\text { (MIC 1.5-2.3 } \mathrm{gg} / \mathrm{mL}), \text { Candida glabrata (MIC } 1.5-2.5 \mu \mathrm{g} / \mathrm{mL}) \text {, and } \\
\text { Candida krusei (MIC 1.6-2.5 } \mathrm{g} / \mathrm{mL})\end{array}$ & [55] \\
\hline $\begin{array}{l}\text { Ruta montana L. } \\
\text { Aerial parts }\end{array}$ & Candida albicans (13-18 mm) and Saccharomyces cerevisiae (12-15 mm) & [67] \\
\hline $\begin{array}{l}\text { Ruta montana L. } \\
\text { Aerial parts }\end{array}$ & Candida albicans (>40 mm) & [70] \\
\hline $\begin{array}{l}\text { Ruta montana L. } \\
\text { Aerial parts }\end{array}$ & Candida albicans (22 mm, MIC > 25,000 $\mu \mathrm{g} / \mathrm{mL}$ ) & [72] \\
\hline $\begin{array}{l}\text { Ruta montana L. } \\
\text { Aerial parts }\end{array}$ & $\begin{array}{l}\text { Aspergillus niger }(12 \mathrm{~mm}), \text { Candida albicans }(32 \mathrm{~mm}), \text { Candida } \\
\text { dubliniensis }(24 \mathrm{~mm}), \text { Candida glabrata }(17 \mathrm{~mm}), \text { Candida } \mathrm{sp} .(13 \mathrm{~mm}) \text {, } \\
\text { Candida tropicalis }(14 \mathrm{~mm}), \text { Cryptococcus neoformans }(20 \mathrm{~mm}), \text { Fusarium } \\
\text { sp. }(14 \mathrm{~mm}), \text { Penicillium sp. }(15 \mathrm{~mm}), \text { Rhodotorula rubra }(11 \mathrm{~mm}) \text {, } \\
\text { Trichophyton mentagrophytes }(15 \mathrm{~mm}) \text {, and Trichosporon sp. }(17 \mathrm{~mm})\end{array}$ & [71] \\
\hline $\begin{array}{l}\text { Ruta montana L. } \\
\text { Aerial parts }\end{array}$ & $\begin{array}{c}\text { Aspergillus oryzae, Botrytis cinerea, Fusarium oxysporum, Fusarium solani, } \\
\text { and Verticillium dahlia with MICs } 100-1100 \mu \mathrm{g} / \mathrm{mL}\end{array}$ & [73] \\
\hline $\begin{array}{l}\text { Ruta tuberculata Forssk. } \\
\text { Aerial parts }\end{array}$ & $\begin{array}{l}\text { Alternaria alternaria }(20 \mathrm{~mm}) \text {, Aspergillus flavus }(17 \mathrm{~mm}) \text {, Aspergillus } \\
\text { fumigatus }(17 \mathrm{~mm}) \text {, Candida albicans }(17 \mathrm{~mm}), \text { Cladosporium herbarum } \\
(34 \mathrm{~mm}) \text {, and Fusarium oxysporum }(16 \mathrm{~mm})\end{array}$ & [18] \\
\hline $\begin{array}{l}\text { Ruta sp. } \\
\text { Aerial parts }\end{array}$ & $\begin{array}{l}\text { Alternaria alternata ( } 31 \mathrm{~mm}) \text {, Aspergillus fumigatus (29 mm), Aspergillus } \\
\text { niger }(24 \mathrm{~mm}), \text { Mucor mucedo ( } 21 \mathrm{~mm}) \text {, and Rhizopus arrhizus }(28 \mathrm{~mm})\end{array}$ & [84] \\
\hline
\end{tabular}

\subsection{Antioxidant Activity}

Oxidative stress is often implicated in several chronic and severe illnesses like diabetes, cancers, cardiovascular diseases, and many more. External supply of antioxidants, either as fresh fruits and vegetables or as therapeutic and preventative commercially available pharmaceutical and/or nutraceutical products, may be necessary to mitigate oxidative stress. Antioxidants are compounds, synthetic (e.g., BHT (butylated hydroxytoluene), BHA (butylated hydroxyanisole) and propyl gallate) or natural (e.g., carotene, ascorbic acid, quercetin, and resveratrol), that can mitigate oxidative stress by virtue of their freeradical-scavenging ability and/or reducing power. The search for new, safe, and effective antioxidants from natural origins has intensified in recent years. As plant essential oils have been shown to possess various degrees of antioxidant capacities, mainly because of the presence of various simple phenolic compounds, e.g., carvacrol, coniferyl alcohol, eugenol, gualacol, and thymol, and have been exploited effectively for their uses as food preservatives and in nutraceutical products $[93,94]$, the volume of research aiming at establishing the antioxidant properties of essential oils from new plant sources and their components has also increased.

As part of this relatively new popular trend in phytochemical research, Ruta essential oils have been investigated for antioxidant activity by various researchers. One of the early investigations into the antioxidant properties of Ruta species was conducted by Kambouche et al. [69] on the essential oil from the aerial parts of $R$. montana from Algeria using the DPPH (2,2-diphenyl-1-picryhydrazyl) radical scavenging assay, where a concentrationdependent antiradical activity was observed. Later, essential oil obtained from the aerial parts of this Ruta species collected from the Middle Atlas Mountains, Morocco, was assessed for radical-scavenging activity using the same assay, and the $\mathrm{IC}_{50}$ value was determined as $548.5 \mu \mathrm{g} / \mathrm{mL}$ compared to that of the positive control ascorbic acid (vitamin C) at $53.4 \mu \mathrm{g} / \mathrm{mL}$ [71]. The radical-scavenging activity was at least two-fold more potent than that of the hydromethanolic extract and the hydromethanolic macerate of the aerial parts. 
The same DPPH radical-scavenging assay was used to determine the radical-scavenging property of the essential oil from the aerial parts of $R$. chalepensis from Tunisia, and a low level of activity (0.6-5.61\%) at a concentration of $200 \mathrm{mg} / \mathrm{mL}$ was detected, which was much less potent than that of the synthetic antioxidant BHT [95]. The essential oils from the Palestinian samples of $R$. chalepensis were investigated for their antioxidant potential solely based on the DPPH assay [33], and a concentration-dependent radical-scavenging activity for all samples was observed, with some differences in activity among the samples collected from three different places, Jerusalem, Hebron, and Jenin, having $\mathrm{IC}_{50}$ values of $6.9,7.8$, and $19.9 \mu \mathrm{g} / \mathrm{mL}$, respectively. The radical-scavenging activity was assumed to be linked to high concentrations of linalyl acetate present in the essential oils. Coimbra et al. [4] and Malik et al. [79] documented the antioxidant property of the essential oils obtained from different plant parts of $R$. graveolens. However, none of these studies was comprehensive enough to establish the antioxidant potential of the essential oils, as the DPPH assay can only reveal the radical-scavenging property, which is one of the several mechanisms for antioxidant activity. For a conclusive and comprehensive understanding of the antioxidant property of any sample, a battery of antioxidants assays, e.g., reducing capacity assay, bleaching assay, scavenging of other radicals, enzymatic assays, etc., should be applied.

A combination of the DPPH assay and the ABTS [2,2'-azinobis-(3-ethylbenzothiazoline6-sulfonate)] radical-scavenging assay was utilized for the determination of the antioxidant potential of the essential oil from the leaves of $R$. chalepensis from Tunisia, and interestingly, a higher radical-scavenging activity was observed with this essential oil than that of the methanolic extract, which normally contains various well-known phenolic and polyphenolic antioxidants [9]. It was suggested that the strong radical-scavenging property of this essential oil could be due to the presence of linalool and menthol. The essential oils from the stems and roots of this plant were also tested, but the potency was much less than that of the essential oil obtained from the leaves. Later, Althaher et al. [28] assessed the antioxidant activity of the essential oil from the aerial parts of the Jordanian $R$. chalepensis using a combination of the DPPH assay and the reducing power assay. Their work demonstrated a significant radical-scavenging property $\left(\mathrm{IC}_{50} 35 \mu \mathrm{g} / \mathrm{mL}\right.$ ) compared to that of the positive control ascorbic acid ( $\mathrm{IC}_{50} 21.2 \mu \mathrm{g} / \mathrm{mL}$ ). A dose-dependent reducing power capacity was observed with this essential oil, and the $\mathrm{EC}_{50}$ (effective dose 50\%) was calculated as $20110 \mu \mathrm{g} / \mathrm{mL}$ compared to $90.6 \mu \mathrm{g} / \mathrm{mL}$ for ascorbic acid, indicating its extremely weak reducing power capacity compared to ascorbic acid. It is known that ascorbic acid is more potent as a reducing agent than as a radical-scavenger, and for the $\mathrm{DPPH}$ assay, it is advisable to use a more potent radical-scavenger like quercetin or gallic acid as a positive standard.

Mohammedi et al. [67] used the DPPH and the reducing power assays to determine the antioxidant activity of the essential oils from the aerial parts of $R$. montana collected from different locations in Algeria. In the $\mathrm{DPPH}$ assay, the $\mathrm{IC}_{50}$ (inhibition concentration $50 \%$ ) values for the samples were in the range from 49.6 to $68.1 \mu \mathrm{g} / \mathrm{mL}$, while the $\mathrm{IC}_{50}$ value representing the reducing power was $46.0-64.4 \mu \mathrm{g} / \mathrm{mL}$. It is interesting to note that the differences in the antioxidant potency among the samples, as determined by the DPPH assay and reducing power assay, were comparable and followed the same pattern, e.g., the most potent radical-scavenging sample as revealed by the DPPH assay also displayed the most potent reducing power. Earlier, a similar approach, combining the DPPH and reducing power assays, was adopted by Benali et al. [72] to assess the antioxidant potential of the essential oil of the aerial parts of R. montana, collected from Taza, Morocco, and the $\mathrm{IC}_{50}$ value for the DPPH radical-scavenging ability was found to be $244.6 \mu \mathrm{g} / \mathrm{mL}$. The reducing power of this essential oil, expressed in milligram equivalence of ascorbic acid per gram of essential oil, was $1.39 \mathrm{mg} / \mathrm{g}$.

None of the studies published for Ruta essential oils assessing their antioxidant potentials appear to have attempted any in vivo studies, enzyme assays, or tried to establish conclusively which components of the essential oils could be responsible for the antioxidant 
activity. Clearly, much more work is needed if any of the Ruta essential oils are to be considered for commercial uses as natural antioxidants.

\subsection{Anti-Inflammatory Activity}

While the anti-inflammatory activity of various extracts of Ruta species, particularly $R$. graveolens, has been well-documented in the literature [4,79], the anti-inflammatory activity of Ruta essential oils has not been studied adequately to date. The anti-inflammatory activity of the essential oils of $R$. chalepensis of Algerian origin was evaluated by the carrageenaninduced paw edema method using the albino mice [20]. It was found that this essential oil at a dose of $0.5 \mathrm{~mL} /$ mouse could significantly reduce carrageenan-induced edema as well as the positive control, dichlofenac. It was assumed that the anti-inflammatory activity of this essential oil could be mediated through the inhibition of inflammation mediators like serotonin, prostaglandin, and histamine. Earlier, a similar anti-inflammatory effect was reported for the essential oil obtained from the aerial parts of $R$. graveolens [96]. None of these studies attempted to establish a link between the composition and the anti-inflammatory property of the Ruta essential oils.

It is well-known that oxidative stress can activate several transcription factors, leading to the differential expression of some genes involved in inflammatory pathways, and thus, any effective reduction in oxidative stress by antioxidants or free-radical-scavengers is expected to result in a reduction in inflammatory responses [97]. As Ruta essential oils have been shown to possess considerable antioxidant or free-radical-scavenging potential as outlined above, it is reasonable to assume that further anti-inflammatory activity studies will potentially reveal anti-inflammatory properties of Ruta essential oils, their components, and their applications in the management of inflammatory diseases and inflammation in general.

\subsection{Antiparasitic Activity}

Parasites are organisms that live and feed on another living being, e.g., animals, humans, insects, or plants, and most often cause harm to the host organism. One of the major traditional medicinal uses of $R$. chalepensis, and other Ruta species in general, is as antiparasitic agents [5], particularly as an anthelmintic medication. In fact, from an ethnopharmacological survey, it was obvious that extracts and essential oils of Ruta species, particularly $R$. graveolens, have long been used as an antiparasitic agent in traditional medicine in Italy [98]. This traditional medicinal use of $R$. chalepensis has prompted antiparasitic activity screening of its essential oils, extracts, and isolated major compounds. The antiparasitic activity of plant essential oils is well-documented in the literature [99], and Ruta essential oils have been investigated for their possible role as natural antiparasitic agents [4]. A study conducted by Castagnino and Orsi [99] demonstrated the efficacy of the essential oil of $R$. graveolens on the control of Varroa destructor (mite) infestation in bee (Apis melifera) colonies. It was found that the essential oil of $R$. graveolens could significantly affect mite mortality levels and the mite infestation rate, and could reduce bee offspring mortality rate by $83.3 \%$. It can be noted that $V$. destructor of the family Varroidae is an external parasitic mite that lives on the honeybee hosts, Apis cerana and Apis melifera.

A protozoa can be free-living or parasitic. Most of the disease-causing protozoa are parasitic. Even free-living protozoa, when they enter the cells or tissues of living beings, become parasitic. Antiprotozoal activity of chalepensin (Figure 5), a 3-prenylated furanocoumarin, isolated from the methanolic extract of the aerial parts of $R$. chalepensis, but also present in small amounts in some of its essential oils [36] (Table 1), was established against the parasite Entamoeba histolytica, which is the major cause of amoebiasis in humans [100]; $84.66 \%$ growth inhibition was observed against E. histolytica at a concentration of $150 \mu \mathrm{g} / \mathrm{mL}$ of chalepensin. 
<smiles>C=CC(C)(C)c1cc2cc3ccoc3cc2oc1=O</smiles>

Figure 5. Structure of chalepensin.

Leishmaniasis is a vector-borne parasitic disease caused by the obligate intracellular protozoic parasites of the genus Leishmania, which mainly affects people living in the tropics, subtropics, and southern Europe. A study conducted with 10 different plant essential oils from Tunisia examined the effectiveness of these oils as potential leishmanicidal agents against Leishmania major and L. infantum [95]. The 2-undecanone-rich (84.2\%) essential oil of the aerial parts of $R$. chalepensis was found to be active only against $L$. infantumi, and interestingly, L. major promastigotes were resistant to this essential oil at a concentration of $8 \mu \mathrm{g} / \mathrm{mL}$. Based on the outcome from the cytotoxicity assay, it was suggested that the leishmanicidal activity of this essential oil might not be completely associated with its cytotoxicity and that other mechanisms of action could be involved.

Although nematodes and various fungi are parasites living in/on animals, humans, or plants, the activities of Ruta essential oils as nematicides and antifungal agents are discussed under different sub-sections later in this review.

\subsection{Cytotoxic Activity}

Cancer is one of the major reasons for human mortality and morbidity. Currently available cancer treatment choices are rather limited, and often produce severe side effects and toxicities. Therefore, the search for new, effective, safe, and affordable anticancer drugs is part of many major modern drug discovery initiatives worldwide, and there are reports on studies looking at the potential of plant essential oils as cytotoxic agents against cancer cells. Ruta essential oils are not an exception, albeit the actual number of studies on cytotoxicity of Ruta essential oils is limited. Althaher et al. [28] studied the cytotoxicity of the essential oil of the aerial parts of $R$. chalepensis collected in Jordan using the MTT [3-(4,5-dimethylthiazol-2-yl)-2,5-diphenyltetrazolium bromide] assay against the MCF-7 (mammary gland carcinoma), T47D (human ductal breast epithelial cancer), Caco-2 (colorectal adenocarcinoma), and MRC-5 (normal human fibroblast) cell lines. A dose-dependent cytotoxic effect of this essential oil was observed against all tested cancer cell lines with $\mathrm{IC}_{50}$ values ranging between 79.3 and $107.7 \mu \mathrm{g} / \mathrm{mL}$, but no cytotoxicity was noted against the normal human fibroblasts (MRC-5). The essential oil was the most cytotoxic to MCF-7 and the least to Caco-2 cell lines. However, no inference to any specific components of the essential oil that might be responsible for this cytotoxicity was made. A low level of cytotoxicity of the essential oil of $R$. chalepensis was previously demonstrated against the murine macrophage cell line RAW264.7 [95].

Antiproliferative, apoptotic, and caspacse-3/7 activities of the essential oil of R. graveolens and its major components were observed against several human cell lines, e.g., MCF-7, HeLa (Henrietta Lacks cervical cancer), Jurkat (T lymphocyte), T24 (transitional cell carcinoma), HF-19 (human fetal lung fibroblasts), and HEK-293 (human embryonic kidney), and the activity was enhanced with the essential oil obtained from mixture treated plants [54]. For example, the $\mathrm{IC}_{50}$ of the untreated essential oil against MCF-7 was $20.1 \mu \mathrm{g} / \mathrm{mL}$, whereas with seaweed (Ascophyllum nodosum) treated essential oil, it was $15.0 \mu \mathrm{g} / \mathrm{mL}$. In the antiproliferation and apoptosis assay, the $\mathrm{IC}_{50}$ values for the untreated and treated (with Ascophyllum nodosum) essential oils ( $\mathrm{IC}_{50}$ values for untreated sample are in parentheses) against other cell lines, HeLa, Jurkat, T24, HF-19, and HEK-293 were 6.5 (5.2), 26.0 (19.5), $95.3(83.9), 122.2$ (90.1), and $>200(>200) \mu \mathrm{g} / \mathrm{mL}$, respectively. The $\mathrm{IC}_{50}$ values for 2-undecanone, one of the major components of this essential oil, against the above cell lines were, respectively, 4.2, 2.1, 8.3, 41.5, 33.3, and $>200 \mu \mathrm{g} / \mathrm{mL}$, while that of the other major compound, 2-nonanone, were 7.1, 3.2, 14.2, 64.1, 57.3, and $>200 \mu \mathrm{g} / \mathrm{mL}$, respectively. Cytotoxicity of the essential oil of $R$. graveolens was also studied against human 
lymphocytes maintained in culture and the mutagenicity was assessed by the Ames test with the Salmonella typhimurium strain TA-100 [83]. Although the concentrated essential oil showed some cytotoxicity (40\% lower cell viability), on subsequent dilutions, it appeared to have lost its cytotoxicity and mutagenicity, suggesting its safety, in low amounts, for human consumption as a medicine.

\subsection{Herbicidal Activity}

Herbicides are compounds or extracts that can kill herbs (plants) or prevent their growth; they can be selective or non-selective. Because of the potential health hazards of herbicides currently available on the market, there has been a renewed interest in discovering new, cost-effective, and safer herbicides, not necessarily as purified compounds from natural sources, but also as crude extracts or essential oils. Ruta essential oils have been shown to possess herbicidal properties, and some examples of these properties are discussed below.

Bouajaj et al. [10] studied the in vitro efficacy of $R$. chalepensis essential oil for its herbicidal potency, and their influence on the germination of shoot and root growth of weeds, Triticum durum and Phalaris canariensis. Later, it was found that the herbicidal activity of the essential oils of $R$. chalepensis was dose-dependent and would depend on the weed species [40]. This essential oil could inhibit germination $(90 \%$ rate at $2 \mu \mathrm{L} / \mathrm{mL}$ concentration) and seedling growth of weeds. The activity could be attributed to the presence of $\alpha$-pinene and other oxygenated monoterpenes in the essential oil of $R$. chalepensis. An emulsion based on $6 \%$ essential oil of the aerial parts of $R$. chalepensis collected from El Fahs region, Tunisia, showed a sprouting inhibitory effect on potatoes [37]. The anti-sprouting effect of this essential oil was dose-dependent. It was found that the final weight of sprout for untreated sample was $4.66 \%$, but the weight for the essential oil treated sample was only $0.98 \%$. The major component of this essential oil, 2-undecanone, was thought to be responsible for this activity.

Faria et al. [60] demonstrated that the essential oil of the aerial parts of $R$. graveolens could completely inhibit the growth of the hairy roots of Solanum tuberosum. The herbicidal or phytotoxic property of $R$. graveolens, however, was reported previously on Raphanus sativas, where this essential oil inhibited the germination and seedling radicle growth [101]. In a recent study, the essential oil obtained from the fresh leaves of $R$. graveolens sourced from Brazil has been shown to significantly inhibit the germination and primary development of Eragrostis plana (lovegrass), which is well-known as an invasive plant, at a low concentration $(0.01 \%)$, and the inhibition could be as much as $57.5 \%$ at a concentration of $0.1 \%$ [102]. In another study [66], the essential oils from the fresh flowers and leaves of this Ruta species were found to affect dose-dependently (at a concentration range 5-20 $\mu \mathrm{L} / \mathrm{mL}$ ) seed germinations and selling growth of Amaranthus retroflexus L., Convolvulus arvensis L., and Rumex crispus L., three well-known weed species in cultivated lands. At a concentration of $20 \mu \mathrm{L} / \mathrm{mL}$, this essential oil could prevent seed germination completely $(100 \%)$.

\subsection{Insecticidal Activity}

Plant essential oils are known to have insecticidal properties and have been employed in ecologically-friendly agricultural operations, including the control of pest insects of stored agricultural products [103]. Ruta essential oils are no exception and have been shown to possess insecticidal activity against various insect species, and have been proposed as natural and eco-friendly insecticides with the potential for replacing harmful conventional insecticides.

One of the earlier studies on the assessment of insecticidal properties of Ruta essential oils was carried out on R. montana essential oil, obtained from its fresh aerial parts collected in Tipaza, Algeria [68], and a clear dose-dependent insecticidal activity against German cockroaches (Blatella germanica) was reported. The highest impact (100\%) was observed with an essential oil concentration of $1.6 \%$. This oil was also found to be effective in killing mosquitoes Culex pipiens with $99 \%$ insecticidal effect at $0.6 \%$ essential oil concentration 
after $30 \mathrm{~min}$. The impact of thionation of the essential oil of $R$. montana on insecticidal activity was explored by Fekhar et al. [70] using the fumigation toxicity assay employing Sitophilus oryzae adults. The non-thionated essential oil of $R$. montana could kill $13 \%$ of insects within $24 \mathrm{~h}$ of exposure, and thionation of the essential oil apparently resulted in an increase in insecticidal activity.

The essential oil of the aerial parts of $R$. chalepensis exhibited significant insecticidal activity against three major pests, coffee berry borer (also known as coffee borer beetle; Hypothenemus hampei; 82.5\% mortality in $24 \mathrm{~h}$ ), antestia bug (Antestiopsis sp.; $87.5 \%$ in $24 \mathrm{~h}$ ), and maize weevil (Sitophilus zeamais; $73.5 \%$ in $24 \mathrm{~h}$ ) [103]. Similar insecticidal activity of this essential oil, having 2-undecanone as the major component, was observed against two flour beetles, Tribolium castaneum and T. confusum in the contact toxicity assay, and the $\mathrm{LD}_{50}$ value was determined as being $0.09-0.13 \mu \mathrm{L} / \mathrm{cm}^{2}$ [32]. The insecticidal activity was attributed to the aliphatic ketone, 2-undecanone, which was previously reported to possess insecticidal properties [47]. Later, Akkari et al. [38] studied the insecticidal properties of the essential oils obtained from the flowers and leaves of $R$. chalepensis. More specifically, they assessed their larvicidal properties. In a recent study, essential oil from $R$. chalepensis growing in Morocco was shown to possess insect repellent and insecticidal properties against the adults of Tribolium castaneum [31]. It was found that, even at a low concentration, e.g., $0.15 \mu \mathrm{L} / \mathrm{mL}$, the mortality rate was $55.56 \%$ after $48 \mathrm{~h}$ of exposure. A mortality rate of $57.9 \%$ could be achieved with a higher dose of $0.31 \mu \mathrm{L} / \mathrm{mL}$ after $24 \mathrm{~h}$. A concentration-dependent insecticidal activity of the essential oil of $R$. chalepensis has been demonstrated further against lesser grain borer (Rhyzopertha dominica) using the fumigant toxicity assay [45]. Low mortalities $(8.36,11.22$ and $15.96 \%)$ were observed, respectively, at $6.45,11.29$, and $16.13 \mu \mathrm{L} / \mathrm{L}$ (air), after $24 \mathrm{~h}$. The mortality rate increased to $100 \%$ when a concentration of $129.03 \mu \mathrm{L} /$ (air) essential oil was applied.

The essential oils from the flowers and leaves of $R$. graveolens afforded an insecticidal compound, 2-isopropyl-5-methylphenol (Figure 4). Both the essential oil and the isolated compound were tested for fumigant toxicity as well as contact toxicity against stored-food pests (Coleoptera insects), e.g., Lasioderma serricorne, Sitophilus zeamais, and S. oryzae [104]. The $\mathrm{LD}_{50}$ values of this essential oil in the fumigant toxicity assay were, respectively, 0.480 and $0.527 \mathrm{mg} / \mathrm{mL}$ against $S$. zeamais and $S$. oryzae, while in the contact toxicity assay the values were 0.592 and $0.618 \mathrm{mg} / \mathrm{cm}^{2}$, respectively. No noticeable insecticidal activity of this essential oil was observed against $L$. serricorne. The $\mathrm{LD}_{50}$ values for the isolated compound, 2-isopropyl-5-methylphenol, in the fumigant toxicity were, 0.192 and $0.211 \mathrm{mg} / \mathrm{mL}$, respectively, against Sitophilus zeamais and S. oryzae, and the values in the contact toxicity assay were 0.187 and $0.192 \mathrm{mg} / \mathrm{cm}^{2}$. There was no significant toxicity observed for this compound against L. serricorne in the fumigant toxicity assay, but it showed activity in the contact toxicity assay with an $\mathrm{LD}_{50}$ value of $0.398 \mathrm{mg} / \mathrm{cm}^{2}$. Ben Chaaban et al. [61] utilized the fumigant toxicity assay to assess the insecticidal potency of the essential oil obtained from $R$. graveolens. A dose-dependent insecticidal activity against Ectomyelois ceratoniae and E. kuehniella was observed with the essential oil, where mortality rate increased with the increase in concentration of the essential oil applied. For the lowest essential oil concentration $(1.81 \mu \mathrm{L} / \mathrm{L}$ air $)$, the percentage mortality of Ectomyelois ceratoniae after $48 \mathrm{~h}$ reached $4 \%$, and $6 \%$ in the case of E. kuehniella. Similarly, for the highest concentration $(54.54 \mu \mathrm{L} / \mathrm{L}$ air), the mortality rates were 62 and $88 \%$, respectively, against Ectomyelois ceratoniae and E. kuehniella with this essential oil.

\subsection{Insect-Repellent Activity}

Several publications have reported the significant insect-repellent activity of Ruta essential oils. In a recent study, essential oil from $R$. chalepensis growing in Morocco was shown to possess insect-repellent properties against the adults of Tribolium castaneum as evaluated by the preferential area method on filter paper using the same conditions as those used for mass rearing $\left(30^{\circ} \mathrm{C}\right.$ temp. and $70 \%$ humidity) [31]. At a dose of $0.038 \mu \mathrm{L} / \mathrm{mL}$, this essential oil demonstrated $100 \%$ repellency after $15 \mathrm{~min}$, and a dose of $0.031 \mu \mathrm{L} / \mathrm{mL}$ 
caused $100 \%$ repellency after 20 min of exposure. It was interesting to note that at a dose of $0.023 \mu \mathrm{L} / \mathrm{mL}$, there was no repellency observed until $10 \mathrm{~min}$, but $100 \%$ repellency was achieved after $25 \mathrm{~min}$. One of the earlier studies on $R$. chalepensis essential oil revealed its insect-repellent property against mosquitoes, mainly Mansonia mosquito (family: Culicidae) populations (Mansonia uniformis, M. nigerrima and M. africana) in Gambella, Ethiopia [105]. At a concentration of $50 \%$ essential oil, the highest level of repellency showed $91.6 \%$ protection, while it was $78.0 \%$ when $40 \%$ concentration was applied. It can be mentioned here that the percentage protection method appears to be a preferred method for evaluating insect repellency to other conventional methods. Conti et al. [46] reported the mosquitorepellent activity of the essential oils of the aerial parts of $R$. chalepensis collected from El Ala, as well as grown in Tunisi, Tunisia, against the most invasive Asian tiger mosquito, Aedes albopictus (Diptera: Culicidae) using the human-bait technique. Essential oil obtained from the wild sample was found to be a good repellent against Aedes albopictus; the $\mathrm{RD}_{50}$ (repellent dose 50\%) and $\mathrm{RD}_{90}$ (repellent dose $90 \%$ ) were $0.000215 \mu \mathrm{L} / \mathrm{cm}^{2}$ and $0.007613 \mu \mathrm{L} / \mathrm{cm}^{2}$ of the skin, respectively. At the highest concentration $\left(0.08 \mu \mathrm{L} / \mathrm{cm}^{2}\right.$ of skin), this essential oil could repel $50 \%$ of mosquitoes for at least $45 \mathrm{~min}$.

Biting deterrence and repellent properties of the essential oils of the aerial parts of $R$. chalepensis growing in Turkey were assessed against mosquitoes [47]. The major compounds present in this essential oil, e.g., 2-undecanone, 2-noanone, and 2-nonyl acetate, were also tested. The biting deterrent activity of the essential oil (10 and $\left.50 \mu \mathrm{g} / \mathrm{cm}^{2}\right), 2$-undecanone $\left(8.5 \mu \mathrm{g} / \mathrm{cm}^{2}\right), 2$-nonanone $\left(9 \mu \mathrm{g} / \mathrm{cm}^{2}\right)$, and 2-nonyl acetate $\left(9.3 \mu \mathrm{g} / \mathrm{cm}^{2}\right)$ was similar to the positive control $N, N$-diethyl-meta-toluamide (DEET) at $4.8 \mu \mathrm{g} / \mathrm{cm}^{2}$ against Aedes aegypti, and the activity of the essential oil at $50 \mu \mathrm{g} / \mathrm{cm}^{2}$ against another mosquito species, Anopheles quadrimaculatus. The cloth patch assay with the essential oil and 2-undecanone revealed their repellent activity against Aedes aegypti at $187 \mu \mathrm{g} / \mathrm{cm}^{2}$ and $108.9 \mu \mathrm{g} / \mathrm{cm}^{2}$. The essential oil obtained from the aerial parts of $R$. chalepensis from Italy showed significant oviposition deterrence activity against the mosquito Aedes albopictus (Diptera: Culicidae) [13], and the arm in cage tests established that this essential oil could repel females of Aedes albopictus with an $\mathrm{ED}_{50}$ (effective dose $50 \%$ ) value of $0.2 \mathrm{~nL} / \mathrm{cm}^{2}$ of skin.

Ruta essential oils, e.g., essential oil of Ruta graveolens, was previously tested for repellent efficacy against other mosquitoes, e.g., A. aegypti with a minimum effective dose of $0.187 \mathrm{mg} / \mathrm{cm}^{2}$ using the cloth patch assay [106]. Prior to this study, Soares et al. [107], examined the insect repellent activity of the essential oil from $R$. graveolens against the Cayenne tick Amblyomma cajennense (Acari: Ixodidae) nymphs, and found this essential oil to have little or no repellent effect.

The published reports as described above on the insect-repellent activities of Ruta essential oils, especially against various mosquito species, suggest that Ruta essential oils could be commercially exploited for mosquito-repellent product development.

\subsection{Larvicidal Activity}

Ruta essential oils possess larvicidal properties. A dose-dependent larvicidal effect of the essential oil of $R$. montana was observed against mosquito larvae; even a dose as low as $1.20 \times 10^{-3} \%$ could exert an excellent outcome with $100 \%$ death of the larvae after three days [68]. The length required for achieving $100 \%$ mortality could be reduced significantly from 3 days down to $1 \mathrm{~h}$ by increasing the concentration of the applied essential oil $\left(9.6 \times 10^{-3 \%} \%\right.$. Akkari et al. [38] studied the insecticidal property of the essential oils obtained from flowers and leaves of $R$. chalepensis using a larvicidal assay involving the larvae of Orgyia trigotephras, where mean mortality time of the larvae subjected to the flower was higher than those treated with the essential oil of the leaves. The larvicidal activity of the essential oil of $R$. graveolens was demonstrated against the fourth instar larvae of Culiseta longiareolata mosquitoes [108], where a concentration-dependent activity was observed. The $\mathrm{LC}_{25}$ (lethal concentration 25\%) and $\mathrm{LC}_{50}$ (lethal concentration 50\%) were determined as 6.96 and 10.11 ppm, respectively. 
The larvicidal activity of $R$. chalepensis essential oil was reported against mosquito larvae about two decades ago [109]. Conti et al. [46] reported larvicidal activity of the essential oils of the aerial parts of $R$. chalepensis collected wild from El Ala, as well as grown in Tunisi, Tunisia, against the fourth instar larvae of the most invasive Asian tiger mosquito, Aedes albopictus (Diptera: Culicidae). Only a slight difference in the activities between the essential oils from the cultivated sample and the wild grown sample was observed, as is evident from the $\mathrm{LD}_{50}$ values of $33.2 \%$ and $35.7 \%$, respectively, in the larvicidal assay.

In another similar work, the larvicidal activity of the essential oils of the aerial parts of $R$. chalepensis growing in Turkey and its major components were assessed against Aedes aegypti and Anopheles quadrimaculatus mosquito larvae [47]. The larvicidal activities of the essential oil against Aedes aegypti and Anopheles quadrimaculatus were evident from the $\mathrm{LD}_{50}$ values, $22.2 \mathrm{ppm}$ and $14.9 \mathrm{ppm}$ at $24 \mathrm{~h}$, respectively. One of the major compounds of this essential oil, 2-undecanone, showed more prominent larvicidal activity that the essential oil against Aedes aegypti ( $\mathrm{LD}_{50} 14.37 \mathrm{ppm}$ ), while the activity of the other major component, 2-nonanone, was less potent ( $\mathrm{LD}_{50} 106.9 \mathrm{ppm}$ ) than that of the essential oil. Furthermore, 2-nonyl acetate did not show any larvicidal activity at the tested concentrations. The $\mathrm{LD}_{50}$ values of 2-undecanone and 2-noanone against Anopheles quadrimaculatus were $14.2 \mathrm{ppm}$ (similar to the essential oil) and $65.5 \mathrm{ppm}$, respectively, at $24 \mathrm{~h}$. Similar larvicidal activity of the essential oil of $R$. chalepensis was reported against the larvae of Aedes aegypti, the New Orleans strain of mosquitoes [30], where the $\mathrm{LD}_{50}$ value was determined as $2.69 \mu \mathrm{g} / \mathrm{mL}$ at $24 \mathrm{~h}$, while this value was $20.13 \mu \mathrm{g} / \mathrm{mL}$ at $24 \mathrm{~h}$ against the larvae of the local population of Aedes aegypti found in Nuevo Leon, Mexico. The essential oil obtained from the aerial parts of $R$. chalepensis from Italy showed significant larvicidal activity against the mosquito Aedes albopictus (Diptera: Culicidae) [13], and the $\mathrm{LD}_{50}$ was determined as $93.6 \mu \mathrm{L} / \mathrm{L}$.

It is not exactly a larvicidal activity, but the larvae-repellent activity of the essential oil of R. graveolens against the neonate larvae of the codling moth (Lepidoptera: Tortricidae) using the barrier test was reported [110]. The repellent property was indicated by a significant number of turn-arounds by codling moth larvae at the barrier. Time required for neonate codling moth larvae to cross essential oil applied to a glass rod in a laboratory was $2.5 \mathrm{~min}$ at a concentration of $0.1 \mathrm{mg} / \mathrm{mL}$ of $R$. graveolens essential oil, and the time increased as the concentration increased, e.g., the time was $42.3 \mathrm{~min}$ at a concentration of $100 \mathrm{mg} / \mathrm{mL}$. The arrestant property of this essential oil was also tested against these larvae, but no detectable activity was observed. da Silva et al. [51] reported the larvicidal activity of the essential oil of fresh leaves of this Ruta species, grown in Brazil, against the third instar larvae of Aedes aegypti revealing the $\mathrm{LD}_{50}$ and $\mathrm{LD}_{90}$ values of $39.6 \%$ and $64.2 \%$, respectively. The essential oil of $R$. graveolens, obtained by microwave hydrodistillation, was found to possess the highest larvicidal activity among several Colombian plants tested for this activity against third instar larvae of Culex quinquefasciatus, with the $\mathrm{LD}_{50}$ value of $7.2 \mu \mathrm{g} / \mathrm{mL}[53]$.

There are only a handful of reports available on the larvicidal activity of the essential oil from $R$. montana. The essential oil of $R$. montana was assessed for the larvae-repellent and larvicidal activities against the flour moth (Ephestia kuehniella) larvae [111]. Interestingly, instead of larvae-repellent, this essential oil demonstrated larvae-attractant activity. However, this essential oil showed larvicidal activity with the larval mortality rate of $56.7 \%$ during the first $24 \mathrm{~h}$, and an $\mathrm{LD}_{50}$ value of $11.6 \mu \mathrm{L} / \mathrm{L}$.

The promising published reports as described above on the larvicidal activities of $R u t a$ essential oils, especially against various mosquito species, suggest that Ruta essential oils could potentially be exploited commercially as mosquito control agents.

\subsection{Nematocidal and Anthelminitic Activity}

Nematodes are parasitic worms of different types that live in animals, humans, insects, and plants. Different plant extracts as well as plant essential oils have long been used in traditional medicines as nematocidal and anthelmintic agents [112]. Ruta essential oils have been studied for nematocidal or anthelmintic property. From an ethnopharmacological 
survey, it is obvious that extracts and essential oils of Ruta species, particularly R. graveolens, have long been used as an anthelmintic agent in traditional medicine in Italy [97].

The nematocidal activity of the essential oil of fresh leaves of $R$. graveolens, growing in Brazil, against juvenile nematodes of Meloidogyne incognita, was evident from its $\mathrm{LD}_{50}$ and $\mathrm{LD}_{90}$ values of 267.2 and $482.0 \mathrm{ppm}$, respectively. A significant level of hatching inhibition activity, with effective concentration $50 \%\left(\mathrm{EC}_{50}\right)<0.15 \mu \mathrm{L} / \mathrm{mL}$ of the essential oil of this Ruta species was reported against the Colombian root-knot nematode Meloidogyne chitwoodi, which is one of the major causes of damage in potato and tomato crops [113]. Earlier, the essential oil of $R$. graveolens from Portugal was shown to be active against the nematode Bursaphelenchus xylophilus, which is the causative nematode for the pine wilt disease that is common in Portuguese pine forests [114,115]. In the direct contact assay, this essential oil demonstrated nematocidal activity with an $\mathrm{LC}_{100}$ (lethal concentration $100 \%$ ) value of $<0.4 \mu \mathrm{L} / \mathrm{mL}$ [114].

A study, conducted by da Silva et al. [51], also established the nematocidal property of the essential oil of $R$. graveolens, and the activity was observed against the juvenile nematodes of Meloidogyne incognita with $\mathrm{IC}_{50}$ (inhibition concentration $50 \%$ ) and $\mathrm{IC}_{90}$ (inhibition concentration $90 \%$ ) values of $267.2 \mathrm{ppm}$ and $482.0 \mathrm{ppm}$, respectively. The nematocidal activity could be attributed to the presence of aliphatic ketones, e.g., 2-undecanone, and 2-nonanone as the major compounds in this essential oil. A similar finding was also published for the essential oil of $R$. graveolens against Meloidogyne incognita, which was part of the search for plant essential oil-based biofumigants for the control of the root knot nematodes on tomato [116]. This essential oil was found to significantly reduce nematode multiplication and gall formation on tomato roots at a dose of $50 \mu \mathrm{L}$ per kilogram of soil. In the most recent study [58], the essential oil of $R$. graveolens was shown to possess significant nematocidal property against the eggs and juveniles of the root-knot nematode Meloidogyne incognita. In the juvenile mortality assay, the mortality ranged from $31-56 \%$ after $24 \mathrm{~h}$ immersion in $0.78-6.25 \mu \mathrm{g} / \mathrm{mL}$ solutions of this essential oil, but the mortality rose above $90 \%$ after $8 \mathrm{~h}$ of exposure to a $1 \mu \mathrm{g} / \mathrm{mL}$ concentration. In the egg hatchability bioassay, it was found that the essential oil of $R$. graveolens could significantly affect the hatchability of $M$. incognita eggs, bringing it down to only $1.2 \%$ after $96 \mathrm{~h}$ egg mass exposure to a $500 \mu \mathrm{g} / \mathrm{mL}$ solution.

Aliphatic ketones from the $R$. chalepensis essential oil were found to induce paralysis on root knot nematodes, which are well-known as plant-parasitic nematodes from the genus Meloidogyne [25]. The nematocidal activity of this essential oil against second-stage juveniles of Meloidogyne incognita and M. javanica was evident from the $\mathrm{EC}_{50}$ (effective concentration $50 \%$ ) values of 77.5 and $107.3 \mu \mathrm{g} / \mathrm{mL}$, respectively, after one day of treatment. The major aliphatic ketone, 2-undecanone, present in this essential oil was also tested for nematocidal activity against these nematodes, and the $\mathrm{EC}_{50}$ values were determined as 206 and $22.5 \mu \mathrm{g} / \mathrm{mL}$, respectively. In addition to 2-undecanone, among the other active components, 2-dodecanone and 2-decanone were the most active, followed by 2-nonanone and 2-tridecanone.

Akkari et al. [38] reported the nematocidal activity of the essential oils of flowers and leaves of $R$. chalepensis against the gastrointestinal parasitic nematode Haemonchus contortus using an in vitro nematocidal assay; the activity was evident from the inhibitory effect of these oils on egg hatching and worm motility as compared to those of the positive control, albendazole. At tested concentrations $(0.125-1.0 \mathrm{mg} / \mathrm{mL})$, essential oils form the flowers and leaves exhibited ovicidal activity, and the essential oil form the leaves was more potent than that of the flowers with $\mathrm{IC}_{50}$ values of 0.145 and $0.398 \mathrm{mg} / \mathrm{mL}$, respectively. The highest level of inhibition of motility $(87.5 \%)$ was achieved with the concentration of $1 \mathrm{mg} / \mathrm{mL}$ and the exposure time of $8 \mathrm{~h}$ for the essential oil of the leaves, whereas at the same concentration and exposure time, the inhibition of motility was found to be $75 \%$ with the essential oil of the flowers.

A dose-dependent nematocidal activity of the essential oil of the aerial parts of $R$. chalepensis as well as its major compounds, e.g., 2-decanone, 2-nonanone, and 2-undecanone, 
was assessed against ewe gastrointestinal nematodes, e.g., Haemonchus contortus, Teladorsagia sp., and Trichostrongylus sp. [12]. The $\mathrm{EC}_{50}$ value after one day of exposure to this essential oil was $1.29 \mathrm{mg} / \mathrm{mL}$, and that of 2-decanone, 2-nonanone, and 2-undecanone were $0.07,0.25$, and $0.88 \mathrm{mg} / \mathrm{mL}$, respectively, revealing that 2 -decanone was the most potent nematicide among the tested compounds.

\subsection{Miscellaneous Activity}

Apart from the activities discussed above, there are a few other activities of Ruta essential oils reported in the literature. Drioueche et al. [117] unveiled the possibility for the use of the essential oil from $R$. montana, which contains high amounts of aliphatic ketones of different bond lengths (Table 1), as a starting material for the synthesis of a natural emulsifier. Although not exactly a bioactivity, the steel corrosion inhibitory activity of the essential oil of $R$. chalepensis was evaluated in aqueous hydrochloric acid $(\mathrm{HCl})$ solution (1 M) using the weight-loss method, potentiodynamic polarization, and electrochemical and impedance spectroscopy, and an increase in efficiency of $77 \%$ was found at a concentration of $2.5 \mathrm{~mL} / \mathrm{L}$ [19].

\section{Ruta Essential Oils, Nanotechnology, and Chitosan}

The term 'nanotechnology' was first introduced by Norio Taniguchi in 1974 [118,119]. However, the pioneering concept of nanotechnology was first presented by Richard Feynman in 1959. Nanotechnology can be defined as the manipulation of matter on an atomic, molecular, and supramolecular scale. It utilizes particles with dimensions of 1-100 nanometers (nm), which are referred to as nanoparticles. This technology has already been playing a major role in advancing and impacting almost all areas of science, especially, drug formulation and delivery. Nanotechnology has recently been applied to the targeted delivery of essential oils in order to enhance their efficacies, and publications demonstrating this new approach have just begun to appear in the literature; for example, enhanced efficacy of essential oils has been demonstrated with chitosan nanoparticles loaded with essential oils against multi-drug-resistant (MDR) Klebsiella pneumoniae [120], and other bacterial species, e.g., Enterococcus faecalis, Escherichia coli, Staphylococcus aureus and Pseudomonas aeruginosa [121]. Because of the nonpolar nature of the essential oils, microencapsulation and/or nanoencapsulation often enhances delivery efficiency of essential oils. It can be noted that chitosan is a biopolymeric sugar (polysaccharide) molecule found in the hard outer shell of shellfish, e.g., crab, lobster and shrimp, and chitosan nanoparticles are used in the delivery of drugs and other bioactive molecules. The hydrophilic nature of chitosan is a weak barrier, but this drawback can be mitigated by creating nanocomposites incorporating hydrophobic essential oils.

Anthracnosis, caused by the pathogenic fungi Colletotrichum gloeosporioides, is a common problem for preserving guava fruits, which are generally highly perishable. Tova et al. [122] proposed an emulsion coating of chitosan with $R$. graveolens essential oil (undecanone $42.6 \%$ and 2 -nonanone $23.5 \%$ ) as a preventative measure for minimizing the loss of guava fruits (Psidium guajava L.) and extending their storage/preservation time at room temperature. While in this emulsion, the essential oil, as well as chitosan, was the active antifungal agent. Additionally, chitosan helped with the emulsion stability. It is known that the smaller the particle size, the larger is the surface area. Thus, it could be envisaged that the reduction of the particle size by using chitosan nanoparticles would further enhance the quality of this emulsion. Most recently, the protecting effect of chitosan-Ruta graveolens essential oil emulsion against Colletotrichum gloeosporioides has also been shown in papaya fruits (Carica papaya L.) [123].

In a similar study, Gonzalez-Locarno et al. [124] demonstrated that an edible coating, based on chitosan-Ruta graveolens essential oil, could prevent microbial decay of gooseberries (Physalis peruviana L.) caused by molds and yeasts, and thus extend storage length, and the chitosan-Ruta graveolens essential oil-based coating was found to be useful for 
increasing the shelf-life of tomatoes (Solanum lycopersicum L.) at low temperature storage by inhibiting the growth of bacteria, mold, and yeast [125].

\section{Conclusions}

Ruta chalepensis, R. graveolens, and R. montana are three most extensively studied Ruta species for the composition and bioactivities of their essential oils, and most of the Ruta samples studied were from Algeria and Tunisia. The essential oils of Ruta are dominated by two aliphatic ketones, 2-undecanone and 2-nonanone, but considerable variations in their amounts could be observed, which is mainly due to differences in climatic conditions, soil quality, geographical sources, collection time, and processing methods. While various bioactivities of Ruta essential oils have been documented in the literature, significant variations in bioactivity profiles and potencies do exist among essential oils from Ruta samples. Most of the bioactivities reported in the literature involve preliminary in vitro screening, and probably have limited clinical relevance. Moreover, it is worth mentioning that there is not enough information available on definitive correlations between biological activities and the compositions of these essential oils, leaving several unresolved questions on the efficacy and practical applications of these essential oils. The true potential of Ruta essential oils resides in their non-medicinal bioactivities, e.g., pesticidal, larvicidal, insecticidal and insect-repellent properties, which can be exploited further for development of commercial agrochemical products.

Author Contributions: All authors contributed equally to the collation of relevant information from an extensive literature search. Additionally, L.N. and S.D.S. prepared, edited, and submitted the manuscript as corresponding authors. All authors have read and agreed to the published version of the manuscript.

Funding: Lutfun Nahar (L.N.) gratefully acknowledges the financial support of the European Regional Development Fund-Project ENOCH (No. CZ.02.1.01/0.0/0.0/16_019/0000868).

Data Availability Statement: All relevant data have been presented as an integral part of this manuscript.

Acknowledgments: Lutfun Nahar gratefully acknowledges the financial support of the European Regional Development Fund-Project ENOCH (No. CZ.02.1.01/0.0/0.0/16_019/0000868).

Conflicts of Interest: The authors declare no conflict of interest.

\section{References}

1. Dr Duke's Phytochemical and Ethnobotanical Databases. Available online: https://phytochem.nal.usda.gov/phytochem/search/ list (accessed on 1 July 2021).

2. Miguel, E.S. Rue (Ruta L., Rutaceae) in traditional Spain: Frequency and distribution of its medicinal and symbolic applications. Econ. Bot. 2003, 57, 231-244. [CrossRef]

3. Pollio, A.A.; De Natale, E.; Appetiti, G.; Aliotta, A.; Touwaide, A. Continuity and change in the Mediterranean medical tradition: Ruta spp. (Rutaceae) in Hippocratic medicine and present practices. J. Ethnopharmacol. 2008, 116, 469-481. [CrossRef]

4. Coimbra, A.T.; Ferreira, S.; Duarte, A.P. Genus Ruta: A natural source of high value products with biological and pharmacological properties. J. Ethnopharmacol. 2020, 260, 113076. [CrossRef]

5. Nahar, L.; Al-Majmaie, S.; Al-Gerushi, A.; Rasul, A.; Sarker, S.D. Chalepin and chalepensin: Occurrence, biosynthesis and therapeutic potential. Molecules 2021, 26, 1609. [CrossRef]

6. Al-Majmaie, S.; Nahar, L.; Rahman, M.M.; Nath, S.; Saha, P.; Talukdar, A.D.; Sharples, G.P.; Sarker, S.D. Anti-MRSA constituents from Ruta chalepensis (Rutaceae) grown in Iraq, and in silico studies on two most active compounds, chalepensin and 6-hydroxyrutin 3',7-dimethyl ether. Molecules 2021, 26, 1114. [CrossRef] [PubMed]

7. Sarker, S.D.; Nahar, L. An introduction to natural products isolation. In Natural Products Isolation, 3rd ed.; Sarker, S.D., Nahar, L., Eds.; Humana Press: Totowa, NJ, USA; Springer: Berlin/Heidelberg, Germany, 2012; pp. 1-26.

8. Li, Y.; Dong, G.; Bai, X.; Aimila, A.; Bai, X.; Maiwulanjiang, M.; Aisa, H.A. Separation and qualitative study of Ruta graveolens L. essential oil components by prep-GC, GC0QTOF-MS and NMR. Nat. Prod. Res. 2020. [CrossRef]

9. Ghazghazi, H.; Aouadhi, C.; Weslati, M.; Trakhna, F.; Maaroufi, A.; Hasnaoui, B. Chemical composition of Ruta chalepensis leaves essential oils and variation in biological activities between leaves, stems and roots methanolic extract. J. Essent. Oil Bear. Plants 2015, 18, 570-581. [CrossRef] 
10. Bouajaj, S.; Romane, A.; Benyamna, A.; Amri, I.; Hanana, M.; Hamrouni, L.; Romdhane, M. Essential oil composition, phytotoxic and antifungal activities of Ruta chalepensis L. leaves from High Atlas Mountains (Morocco). Nat. Prod. Res. 2014, 28, $1910-1914$. [CrossRef] [PubMed]

11. Tedone, L.; Costa, R.; De Grazia, S.; Ragusa, S.; Mondello, L. Monodimensional (GC-FID and GC-MS) and comprehensive two-dimensional gas chromatography for the assessment of volatiles and fatty acids from Ruta chalepensis aerial parts. Phytochem. Anal. 2014, 25, 468-475. [CrossRef]

12. Ortu, E.; Sanna, G.; Scala, A.; Pulina, G.; Caboni, P.; Battacone, G. In vitro anthelmintic activity of active compounds of the fringed rue Ruta chalepensis against dairy ewe gastrointestinal nematodes. J. Helmenthol. 2017, 91, 447-453. [CrossRef]

13. Bedini, S.; Flamini, G.; Ascrizzi, R.; Venturi, F.; Ferroni, G.; Bader, A.; Girardi, J.; Conti, B. Essential oils sensory quality and their bioactivity against the mosquito Aedes albopictus. Sci. Rep. 2018, 8, 17857. [CrossRef]

14. Ruiz, C.; Diaz, C.; Rojas, R. Chemical composition of essential oils from 10 Peruvian aromatic plants. Rev. Soc. Quim. Peru 2015, 81, 81-94.

15. Bennaoum, Z.; Benhassini, H.; Falconieri, D.; Piras, A.; Porcedda, S. Chemical variability in essential oils from Ruta species among seasons and its taxonomic and ecological significance. Nat. Prod. Res. 2017, 31, 2329-2334. [CrossRef] [PubMed]

16. Kuzovkina, I.N.; Szarka, S.; Hethelyi, E.; Lemberkovics, E.; Szoke, E. Composition of essential oil in genetically transformed roots of Ruta graveolens. Russ. J. Plant. Physiol. 2009, 56, 846-851. [CrossRef]

17. Amdouni, T.; Abdallah, S.B.; Msilini, N.; Merck, F.; Chebbi, M.; Lachaal, M.; Karray-Bouraoui, N.; Ouerghi, Z.; Fernandez, X. Effect of salt stress on the antimicrobial activity of Ruta chalepensis essential oils. Acta Physiol. Plant. 2016, 38, 147. [CrossRef]

18. Haddouchi, F.; Chaouche, T.M.; Zaouali, Y.; Ksouri, R.; Attou, A.; Benmansour, A. Chemical composition and antimicrobial activity of the essential oils from four Ruta species growing in Algeria. Food Chem. 2013, 141, 253-258. [CrossRef]

19. Khadraoui, A.; Khelifa, A.; Boutoumi, H.; Hamitouche, H.; Mehdaoui, R.; Hammouti, B.; Al-Deyab, S.S. Adsorption and inhibitive properties of Ruta chalepensis L. oil as a green inhibitor of steel in $1 \mathrm{M}$ hydrochloric acid medium. Int. J. Electrochem. Sci. 2014, 9, 3334-3348.

20. Boudjema, K.; Mouhouche, M.; Guerdouba, A.; Hali, L. Composition, physicochemical analysis, antimicrobial and antiinflammatory activities of the essential oils obtained from Ruta chalepensis L. growing wild in northern Algeria. J. Chem. Soc. Pak. 2018, 40, 1054-1062.

21. Tampe, J.; Parra, L.; Huiquil, K.; Quiroz, A. Potential repellent activity of the essential oil of Ruta chalepensis (Linnaeus) from Chile against Aegorhinus superciliosus (Guerin) (Coleoptera: Curculionidae). J. Soil Sci. Plant Nutr. 2016, 16, 48-59. [CrossRef]

22. Arambula, C.I.; Diaz, C.E.; Garcia, M.I. Performance, chemical composition and antibacterial activity of the essential oil of Ruta chalepensis and Origanum Vulgare. J. Phys. Conf. Ser. 2019, 1386, 012059. [CrossRef]

23. Pino, O.; Sanchez, Y.; Rojas, M.M.; Abreu, Y.; Correa, T.M.; Martinez, D.; Montes de Oca, R. Chemical composition and antibacterial activity of the essential oil from Ruta chalepensis L. Rev. Prot. Veg. 2014, 29, 220-225.

24. Tzakou, O.; Couladis, M. Essential oil of Ruta chalepensis L. from Greece. J. Essent. Oil Res. 2001, 13, 258-259. [CrossRef]

25. Ntalli, N.G.; Manconi, F.; Leonti, M.; Maxia, A.; Caboni, P. Aliphatic ketones from Ruta chalepensis (Rutaceae) induce paralysis on root knot nematodes. J. Agric. Food Chem. 2011, 59, 7098-7103. [CrossRef]

26. Bagchi, G.D.; Dwivedi, P.D.; Singh, A.; Haider, F.; Naqvi, A.A. Variations in essential oil constituents at different growth stages of Ruta chalepensis on cultivation at north Indian plains. J. Essent. Oil Res. 2003, 15, 262-264.

27. Rustaiyan, A.; Khossravi, M.; Sultani-Lotfabadi, F.; Yari, M.; Masoudi, S.; Monfared, A. Constituents of the essential oil of Ruta chalepensis L. from Iran. J. Essent. Oil Res. 2002, 14, 378-379. [CrossRef]

28. Althaher, A.R.; Oran, S.A.; Bustanii, Y.K. Phytochemical analysis, in vitro assessment of antioxidant properties and cytotoxic potential of ruta chalepensis essential oil. J. Essent. Oil Bear. Plants 2020, 23, 1409-1421. [CrossRef]

29. Khoury, M.; Stien, D.; Quaini, N.; Eparvier, V.; Apostolides, N.A.; Beyrouthy, M. Chemical composition and antimicrobial activity of the essential oil of Ruta chalepensis L. growing wild in Lebabon. Chem. Biodivers. 2014, 11, 1990-1997. [CrossRef] [PubMed]

30. Lopez, L.A.P.; de la Torre, Y.C.; Cirio, A.T.; de Torres, N.W.; Suarez, A.E.F.; Aranda, R.S. Essential oils from Zanthoxylum fagara Wild Lime. Ruta chalepensis L. and Thymus vulgaris L.: Composition and activity against Aedes aegypti larvae. Pak. J. Pharm. Sci. 2015, 28, 1911-1915.

31. Najem, M.; Bammou, M.; Bachiri, L.; Bouiamrine, E.; Ibijbijen, J.; Nassiri, L. Ruta chalepensis L. essential oil has a biological potential for natural fight against the pest stored foodstuffs: Tribolium castaneum Herbst. Evid. Based Complement. Altern. Med. 2020, 2020, 5739786. [CrossRef] [PubMed]

32. Abbad, A.; Kasrati, A.; Jamali, C.A.; Zeroual, S.; Mohamed, T.B.; Spooner-Hart, R.; Leach, D. Isecticidal properties and chemical composition of essential oils of some aromatic herbs from Morocco. Nat. Prod. Res. 2014, 28, 2338-2341. [CrossRef]

33. Jaradat, N.; Adwan, L.; K'aibni, S.; Zaid, A.N.; Shtaya, M.J.Y.; Shraim, N.; Assali, M. Variability of chemical compositions and antimicrobial and antioxidant activities of Ruta chalepensis leaf essential oils from three Palestinian regions. BioMed Res. Int. 2017, 2017, 2672689. [CrossRef]

34. Perestrelo, R.; Silva, C.L.; Rodriguez, F.; Caldeira, M.; Camara, J.S. A powerful approach to explore the potential medicinal plants as a natural source of odor and antioxidant compounds. J. Food Sci. Technol. 2016, 53, 132-144. [CrossRef]

35. Alonso-Miguel, H.; Jose Perez-Alonso, M.; Cristina Soria, A.; Blanco Martinez, M. Composition of essential oils of different species of "pepper" of the Piper, Pimenta, Lindera, Ruta, Schinus and Zanthoxylum genera. Bot. Complut. 2021, 44, 103-113. [CrossRef] 
36. Krayni, H.; Fakhfakh, N.; Kossentini, M.; Zouari, S. Fruits of Ruta chalepensis L. (Rutaceae) as a source of 2-undecanone. J. Essent. Oil Bear. Plants 2018, 21, 789-795. [CrossRef]

37. Lengliz, O.; Mejri, J.; Abderrabba, M.; Khalifa, R.; Mejri, M. Ruta chalepensis L. essential oil: A new anti-sprouting agent for potatoes bioconservation. J. Chem. 2018, 2018, 8547851. [CrossRef]

38. Akkari, H.; Ezzine, O.; Dhahri, S.; B'chir, F.; Rekik, M.; Hajaji, S.; Darghouth, M.A.; Jamaa, M.L.B.; Gharbi, M. Chemical composition, insecticidal and in vitro anthelmintic activities of Ruta chalepensis (Rutaceae) essential oils. Ind. Crop. Prod. 2015, 74, 745-751. [CrossRef]

39. Krayni, H.; Zouari, S.; Chouajeb, H.; Fakhfakh, N.; Kossentini, M.; Zouari, N. Variations in the essential oil composition from different organs of Ruta chalepensis L. (Rutaceae) growing wild in Tunisia. J. Essent. Oil Bear. Plants 2015, 18, 1495-1499. [CrossRef]

40. Bouabidi, W.; Hanan, M.; Gargouri, S.; Amri, I.; Fezzani, T.; Ksontini, M.; Iamoussi, B.; Hamrouni, L. Chemical composition, phytotoxic and antifungal properties of Ruta chalepensis L. essential oils. Nat. Prod. Res. 2015, 29, 864-868. [CrossRef]

41. Khadhri, A.; Bouali, I.; Belkhir, S.; El Mokni, R.; Smiti, S.; Almeida, C.; Noggueira, J.M.F.; Araujo, M.E.M. Chemical variability of two essential oils of Tunisian Rue: Ruta montana and Ruta chalepensis. J. Essent. Oil Bear. Plants 2014, 27, 445-451. [CrossRef]

42. Aouadhi, C.H.; Ghazghazi, H.; Hamrouni, S.; Hasnaoui, B.; Maaroufi, A. In vitro antifungal activity of the essential oil and the methanolic extract of Ruta chalepensis. Archives de l'Institut Pasteur de Tunis 2013, 90, 39-46. [PubMed]

43. Mejri, J.; Abderrabba, M.; Mejri, M. Chemical composition of the essential oil of Ruta chalepensis L. Influence of drying, hydrodistillation duration and plant parts. Ind. Crop. Prod. 2010, 32, 671-673. [CrossRef]

44. Tounsi, M.S.; Wannes, W.A.; Ouerghemmi, I.; Msaada, K.; Smaoui, A.; Marzouk, B. Variation in essential oil and fatty acid composition in different organs of cultivated and growing wild Ruta chalepensis L. Ind. Crop. Prod. 2011, 33, 617-623. [CrossRef]

45. Ncibi, S.; Attia, S.; Diop, S.M.B.; Ammar, M.; Hance, T. Bio-insecticidal activity of three essential oils against Rhyzopertha dominica (Fabricius, 1792) (Coleoptera: Bostrichidae). Afr. Entomol. 2020, 28, 339-348. [CrossRef]

46. Conti, B.; Leonardi, M.; Pistelli, L.; Profeti, R.; Ouerghemmi, I.; Benelli, G. Larvicidal and repellent activity of essential oils from wild and cultivated Ruta chalepensis L. (Rutaceae) against Aedes albopictus Skuse (Diptera: Culicidae), and arbovirus vector. Parasitol. Res. 2013, 112, 991-999. [CrossRef]

47. Ali, A.; Demirci, B.; Kiyan, H.T.; Bernier, U.R.; Tsikolia, M.; Wedge, D.E.; Khan, I.A.; Baser, K.H.C.; Tabanca, N. Biting deterrence, repellency, and larvicidal activity of Ruta chalepensis (Sapindales: Rutaceae) essential oil and its major individual constituents against mosquitoes. J. Med. Entomol. 2013, 50, 1267-1274. [CrossRef]

48. Boudiar, T.; Labed, I.; Safaei-Ghomi, J.; Kabouche, A.; Kabouche, Z. Analysis of the essential oil of Ruta chalepensis subsp. Angustifolia from Algeria. J. Essent. Oil Bear. Plants 2011, 14, 792-795. [CrossRef]

49. Dob, T.; Dahmane, D. Volatile constituents of the essential oil of Ruta chalepensis L. subsp. angustifolia (Pers.) P. Cout. J. Essent. Oil Res. 2008, 20, 306-309. [CrossRef]

50. Orlanda, J.F.F.; Nascimento, A.R. Chemical composition and antibacterial activity of Ruta graveolens L. (Rutaceae) volatile oils, from Sao Luis, Maranhao, Brazil. S. Afr. J. Bot. 2015, 99, 103-106. [CrossRef]

51. da Silva, F.G.E.; Mendez, F.R.D.; Assuncao, J.C.D.; Santiago, G.M.P.; Bezerra, M.A.X.; Barbosa, F.G.; Mafezoli, J.; Rocha, R.R. Seasonal variation, larvicidal and nematocidal activities of the leaf essential oil of Ruta graveolens L. J. Essent. Oil Res. 2014, 26, 204-209. [CrossRef]

52. Semerdjieva, I.B.; Burducea, M.; Astatkie, T.; Zheljazkov, V.D.; Dincheva, I. Essential oils composition of Ruta graveolens L. fruits and Hyssopus officinalis subsp. Aristatus (Godr.) Nyman biomass as a function of hydrodistillation time. Molecules 2019, $24,4047$. [CrossRef]

53. Rosado-Solano, D.N.; Restrepo-Manrique, R.; Jaramillo-Perez, V.M.; Puerto-Galvis, C.E.; Kouznetsov, V.V.; Vargas-Mendez, L.Y. Larvicidal activity of essential oils and extracts of Colombian plants against Culex quinquefasciatus (Diptera: Culicidae). Iteckne 2018, 15, 79-87. [CrossRef]

54. Mahmoud, E.A.; Elansary, H.O.; El-Ansary, D.O.; Al-Mana, F.A. Elevated bioactivity of Ruta graveolens against cancer cells and microbes using seaweeds. Processes 2020, 8, 75. [CrossRef]

55. Attia, E.Z.; El-Baky, R.M.A.; Desoukey, S.Y.; Mohamed, M.A.E.; Bishr, M.M.; Kamel, M.S. Chemical composition and antimicrobial activities of essential oils of Ruta graveolens plants treated with salicylic acid under drought stress conditions. Future J. Pharm. Sci. 2018, 4, 254-264. [CrossRef]

56. Reddy, D.N.; Al-Rajab, A.J. Chemical composition, antibacterial and antifungal activities of Ruta graveolens L. volatile oil. Cogent Chem. 2016, 2, 1220055. [CrossRef]

57. Bohidar, S.; Thirunavoukkarasu, M. Essential oils from leaves of micropropagated Ruta Graveolens. J. Essent. Oil Bear. Plants 2012, 15, 296-299. [CrossRef]

58. D'Addabbo, T.; Argentieri, M.P.; Laquale, S.; Candido, V.; Avato, P. Relationship between chemical composition and nematocidal activity of different essential oils. Plants 2020, 9, 1546. [CrossRef]

59. Jeon, J.-H.; Park, J.-H.; Lee, H.-S. 2-Isopropyl-5-methylphenol isolated from Ruta graveolens and its structural analogs show antibacterial activity against food borne bacteria. J. Korean Soc. Appl. Biol. Chem. 2014, 57, 485-490. [CrossRef]

60. Faria, J.M.S.; Rodrigues, A.M.; Sena, I.; Moiteiro, C.; Bennett, R.N.; Mota, M.; Figueiredo, A.C. Bioactivity of ruta graveolens and Satureja montana essential oils on Solanum tuberosum hairy roots and Solanum tuberosum hairy roots with Meloidogyne chitwoodi co-cultures. J. Agric. Food Chem. 2016, 64, 7452-7458. [CrossRef] 
61. Ben Chaaban, S.; Hamdi, S.H.; Mahjoubi, K.; Ben Jemaa, J.M. Composition and insecticidal activity of essential oils from Ruta graveolens, Mentha pulegium and Ocimum basilicum against Ectomyelois ceratoniae Zeller and Ephestia kuehniella Zeller (Lepidoptera: Pyralidae). J. Plant. Dis. Prot. 2019, 126, 237-246. [CrossRef]

62. Yosra, B.; Manef, A.; Sameh, A. Biological study from Ruta plants extracts growing in Tunisia. Iran. J. Chem. Chem. Eng. Int. Engl. Ed. 2019, 38, 85-89.

63. Bejaoui, I.; Karmous, T. Tunisian Ruta graveolens essential oil: Influence of factors on its yield and composition. J. Essent. Oil Bear. Plants 2012, 15, 276-282. [CrossRef]

64. Fredj, M.B.H.; Marzouk, B.; Chraief, I.; Boukef, K.; Marzouk, Z. Analysis of Tunisian Ruta graveolens L. oil from Jemmel. J. Food Agric. Environ. 2007, 5, 52-55.

65. Chaftar, N.; Girardot, M.; Quellard, N.; Labanowski, J.; Ghrairi, T.; Hani, K.; Frere, J.; Imbert, C. Activity of six essential oils extracted from Tunisian plants against Legionella pneumophila. Chem. Biodivers. 2015, 12, 1565-1574. [CrossRef]

66. Bozhuyuk, A.U. Herbicidal activity and chemical composition of two essential oils on seed germination and seedling growths of three weed species. J. Essent. Oil Bear. Plants 2020, 23, 821-831. [CrossRef]

67. Mohammedi, H.; Mecherara-Idieri, S.; Hassani, A. Variability in essential oil composition, antioxidant and antimicrobial activities of Ruta montana L. collected from different geographical regions in Algeria. J. Essent. Oil Res. 2019, 32, 23-36. [CrossRef]

68. Boutoumi, H.; Moulay, S.; Khodja, M. Essential oil from Ruta montana L. (Rutaceae): Chemical composition, insecticidal and larvicidal activities. J. Essent. Oil Bear. Plants 2009, 12, 714-721. [CrossRef]

69. Kambouche, N.; Merah, B.; Bellahouel, S.; Bouaved, I.; Dicko, A.; Derdour, A.; Younos, C.; Soulimani, R. Chemical composition and antioxidant potential of Ruta montana L. essential oil from Algeria. J. Med. Food 2008, 11, 593-595. [CrossRef]

70. Fekhar, N.; Moulay, S.; Asma, D.; Krea, M.; Boutoumi, H.; Benmaamar, Z. Thionation of essential oils from Algerian Artemisia herba -alba L. and Ruta montana L.: Impact on their antimicrobial and insecticidal activities. Chem. J. Mold. 2017, $12,50-57$. [CrossRef]

71. Drioiche, A.; Amine, S.; Boutahiri, S.; Saidi, S.; Ailli, A.; Rhafouri, R.; Mahjoubi, M.; El Hilali, F.; Mouradi, A.; Eto, B.; et al. Antioxidant and antimicrobial activity of essential oils and phenolic extracts from the aerial parts of Ruta montana L. of the Middle Atlas Mountains-Morocco. J. Essent. Oil Bear. Plants 2020, 23, 902-917. [CrossRef]

72. Benali, T.; Habbadi, K.; Khabbach, A.; Marmouzi, I.; Zengin, G.; Bouyahya, A.; Chamkhi, I.; Chtibi, H.; Anniz, T.; Achbani, E.; et al. GC-MS analysis, antioxidant and antimicrobial activities of Achillea odorata subsp. Pectinata and Ruta montana essential oils and their potential use as food preservatives. Foods 2020, 9, 668. [CrossRef]

73. Hammami, I.; Smaoui, S.; Ben Hsouna, A.; Hamdi, N.; Triki, M.A. Ruta montana L. leaf essential oil and extracts: Characterization of bioactive compounds and suppression of crown gall disease. EXCLI J. 2015, 14, 83-94. [PubMed]

74. Nakatsu, T.; Lupo, A.T., Jr.; Chinn, J.W., Jr.; Kang, R.K.L. Biological activity of essential oils and their constituents. Stud. Nat. Prod. Chem. 2000, 21, 571-631.

75. Perricone, M.; Arace, E.; Corbo, M.R.; Sinigaglia, M.; Bevilacqua, A. Bioactivity of essential oils: A review on their interaction with food components. Front. Microbiol. 2015, 6, 76. [CrossRef]

76. Mancianti, F.; Ebani, V.V. Biological activity of essential oils. Molecules 2020, 25, 678. [CrossRef]

77. Williams, L.R.; Stockley, J.K.; Home, V.N. Essential oils with high antimicrobial activity for therapeutic use. Int. J. Aromather. 1998, 8, 30-40. [CrossRef]

78. Nogueira, J.C.R.; Diniz, M.D.F.M.; Lima, E.O. In vitro antimicrobial activity of plants in acute otitis externa. Braz. J. Otorhinolaryngol. 2008, 74, 118-124. [CrossRef]

79. Malik, S.; Morales, D.F.C.; do Amaral, F.M.M.; Rebeiro, M.N.S. Ruta graveolens L.: Phytochemistry, pharmacology and biotechnology. In Transgenesis and Secondary Metabolism; Jha, S., Ed.; Springer: Cham, Switzerland, 2017; pp. 177-204.

80. Gibka, J.; Kunicka-Styczynska, A.; Glinkski, M. Antimicrobial activity of undecane-2-one, undecane-2-ol and their derivatives. J. Essent. Oil Bear. Plants 2009, 12, 605-614. [CrossRef]

81. Pino-Perez, O.; Rojas-Fernandez, M.M.; Sanchez-Perez, Y.; Espinosa-Castano, I. Antibacterial activity of essential oils obtained from plants of Cuban origin against Streptococcus Suis. Rev. Salud Anim. 2018, 40, e03.

82. Owlia, O.; Saderi, H.; Rasooli, I.; Sefidkom, F. Antimicrobial characteristics of some herbal oils on Pseudomonas aeruginosa with special reference to their chemical compositions. Iran. J. Pharm. Res. 2009, 8, 107-114.

83. Mena-Huertas, S.J.; Garcia-Lopez, J.P.; Nicola-Benavides, S.N.; Yepez-Chamorro, M.C. Cytotoxic and mutagenic innocuousness of essential oils of Rosmarinus officinalis L. and Ruta graveolens L. as a promising complimentary treatment of Helicobacter pylori infection. Actual. Biol. 2016, 39, 37-44.

84. Saksena, N.; Tripathi, H.S. Plant volatiles in relation to fungistasis. Fitoterapia 1985, 56, 243-244.

85. Sephavand, A.; Eliasy, H.; Mohammadi, M.; Safarzadeh, A.; Azarbaijani, K.; Shahsavari, S.; Alizadeh, M.; Beyranvand, F. A review of the most effective medicinal plants for dermatophytosis in traditional medicine. Biomed. Res. Ther. 2018, 5, 2378-2388. [CrossRef]

86. Duarte, Y.; Pino, O.; Infante, D.; Sanchez, Y.; Travieso, M.D.C.; Martinez, B. In vitro effect of essential oils on Alternaria solani Sorauer. Rev. Prot. Veg. 2013, 28, 54-59.

87. Soares, C.; Morales, H.; Faris, J.; Figueiredo, A.C.; Pedro, L.G.; Venancio, A. Inhibitory effect of essential oils on growth and aflatoxins production by Aspergillus parasiticus. World Mycotoxin J. 2016, 9, 525-534. [CrossRef] 
88. Belem, L.F.; Lima, E.O.; Barbosa Filho, J.M.; Silva Filho, R.N.; Lima, J.R.; Casimiro, G.S. Antifungal activity of essential oils 'in vitro' against strains of Malassezia furfur. Rev. Bras. Plantas Med. 2003, 6, 77-83.

89. Donadu, M.G.; Peralta-Ruiz, Y.; Usai, D.; Maggio, F.; Molina-Hernandez, J.B.; Rizzo, D.; Bussu, F.; Rubino, S.; Zanetti, S.; Paparella, A.; et al. Colombian essential oil of Ruta graveolens against nosocomial antifungal resistant Candida strains. J. Fungi 2021, 7, 383. [CrossRef] [PubMed]

90. Garcia, R.A.; Juliatti, F.C.; Barbosa, K.A.G.; Cassemiro, T.A. Antifungal activity of vegetable oils and extracts against Sclerotinia sclerotiorum. Biosci. J. 2012, 28, 48-57.

91. Knaak, N.; da Silva, L.D.; Andreis, T.F.; Fiuza, L.M. Chemical characterization and anti-fungal activity of plant extracts and essential oils on the Bipolaris oryzae and Gerlachia oryzae phytopathogens. Aust. Plant. Pathol. 2013, 42, 469-475. [CrossRef]

92. Baseggio, E.R.; Giacobbo, C.L.; Galon, L.; Milanesi, P.M. Volatile compounds of essential oils in inhibition of the development of Monilinia fructicola in vitro. Rev. Cienc. Agrar. 2019, 42, 181-190.

93. Amorati, R.; Foti, M.C.; Valgimigli, L. Antioxidant activity of essential oils. J. Agric. Food Chem. 2013, 61, 10835-10847. [CrossRef]

94. Torres-Martinez, R.; Garcia-Rodriguez, Y.M.; Rios-Chavez, P.; Saavedra-Molina, A.; Lopez-Menza, J.E.; Ochoa-Zarzosa, A.; Garciglia, R.S. Antioxidant activity of the essential oil and its major terpenes of Satureja macrostema (Moc. And Sesse ex Benth.) Briq. Pharmacogn. Mag. 2017, 13, S875-S880.

95. Ahmed, S.B.; Sghaier, R.M.; Guesmi, F.; Kaabi, B.; Mejri, M.; Attia, H.; Laouini, D.; Smaali, I. Evaluation of antileishmanial, cytotoxic and antioxidant activities of essential oils extracted from plants issued from the leishmaniasis-endemic region of Send (Tunisia). Nat. Prod. Res. 2011, 25, 1195-1201. [CrossRef]

96. Nonnenmacher, J.L.; Mikulski, B.S.; Roman, S.S. Anti-inflammatory activity of the essential oil and hydroalcoholic extract of Ruta graveolens L. (Rue) on ear edema in mice. Perspectiva 2016, 41, 125-1340.

97. Hussain, T.; Tan, B.; Yin, Y.; Blachier, F.; Tossou, M.C.B.; Rahu, N. Oxidative stress and inflammation: What polyphenols can do for us? Oxid. Med. Cell. Longev. 2016, 2016, 7432797. [CrossRef]

98. Guarrera, P.M. Traditional antihelmintic, antiparasitic and repellent uses of plants in Central Italy. J. Ethnopharmacol. 1999, 68, 183-192. [CrossRef]

99. Castagnino, G.L.B.; Orsi, R.O. Natural products for the control of the mite Varroa destructor in Africanized bees. Pesqui. Agropecu. Bras. 2012, 47, 738-744. [CrossRef]

100. Quintanilla-Licea, R.; Mata-Cardenas, B.D.; Vargas-Villareal, J.; Bazaldua-Rodriguez, A.F.; Angeles-Hernanandez, I.K.; GarzaGonzalez, J.N.; Hernandez-Garcia, M.E. Antiprotozoal activity against Entamoeba histolytica of plants used in northeast Mexican medicine. Bioactive compounds from Lippia graveolens and Ruta Chalepensis. Molecules 2014, 19, 21044-21065. [CrossRef]

101. De Feo, V.; de Simone, F.; Senatore, F. Potential allelochemicals from the essential oil of Ruta graveolens. Phytochemistry 2002, 61, 573-578. [CrossRef]

102. Maldaner, J.; Steffen, G.P.K.; Missio, E.L.; Saldanha, C.W.; De Morais, R.M.; Steffen, R.B. Rue and Brazillian peppertree essential oils inhibit the germination and initial development of the invasive plant lovegrass. Int. J. Environ. Stud. 2020, 77, 255-263. [CrossRef]

103. Mendesil, E.; Tadesse, M.; Negash, M. Efficacy of plant essential oils against two major insect pests of coffee (coffee berry borere, Hypothenemus hampei, and antestia bug, Antestiopsis intricate) and maize weevil, Sitophilus zeamais. Arch. Phytopathol. Plant. Prot. 2012, 45, 366-372. [CrossRef]

104. Jeon, J.-H.; Lee, S.-G.; Lee, H.-S. Isolation of insecticidal constituent from Ruta graveolens and structure-activity relationship studies against stored-food pests (Coleoptera). J. Food Prot. 2015, 78, 1536-1540. [CrossRef]

105. Hadis, M.; Lulu, M.; Mekonnen, Y.; Asfaw, T. Field trials on the repellent activity of four plant products against mainly Mansonia population in western Ethiopia. Phytother. Res. 2003, 17, 202-205. [CrossRef]

106. Tabanca, N.; Demirci, B.; Kiyan, H.T.; Ali, A.; Bernier, U.R.; Wedge, D.E.; Khan, I.A.; Başer, K.H.C. Repellent and larvicidal activity of Ruta graveolens essential oil and its major individual constituents against Aedes aegypti. Planta Med. 2012, 78, 90. [CrossRef]

107. Soares, S.F.; Borges, L.M.F.; Braga, R.D.; Ferreira, L.L.; Louly, C.C.B.; Tresvenzol, L.M.F.; de Paula, J.R.; Ferri, P.H. Repellent activity of plant-derived compounds against Amblyomma cajennense (Acari: Ixodidae) nymphs. Vet. Parasitol. 2010, 167, 67-73. [CrossRef]

108. Bouabida, H.; Dris, D. Effect of rue (Ruta graveolens) essential oil on mortality, development, biochemical and biomarkers of Culiseta longiareolata. S. Afr. J. Bot. 2020, 133, 139-143. [CrossRef]

109. Lahlou, M.; Berrada, R.; Hmamouchi, M.; Lyagoubi, M. Effect of some Moroccan medicinal plants on mosquito larvae. Therapie 2001, 56, 193-196.

110. Landolt, P.J.; Hofstetter, R.W.; Biddick, L.L. Plant essential oils as arrestants and repellents for neonate larvae of the codling moth (Lepidoptera: Tortricidae). Environ. Entomol. 1999, 28, 954-960. [CrossRef]

111. Bouzeraa, H.; Bessila-Bouzeraa, M.; Labed, N. Repellent and fumigant toxic potential of three essential oils against Ephestia kuehniella. Biosyst. Divers. 2019, 27, 349-353. [CrossRef]

112. Kumarasingha, R.; Preston, S.; Yeo, T.-C.; Lim, D.S.L.; Tu, C.-L.; Jilian, E.A.P.; Shaw, M.; Gasser, R.B.; Boag, P.R. Anthelmintic activity of selected ethno-medicinal plant extracts on parasitic stages of Haemonchus contortus. Parasites Vectors 2016, 9, 187. [CrossRef] [PubMed]

113. Faria, J.M.S.; Sena, I.; Ribeiro, B.; Rodriguez, A.M.; Maleita, C.M.N.; Abrantes, I.; Bennett, R.; Mota, M.; Figueiredo, A.C.D. First report on Meloidogyne chitwoodi hatching inhibition activity of essential oils and essential oils fractions. J. Pest. Sci. 2016, 89, 207-217. [CrossRef] 
114. Faria, J.M.S.; Barbosa, P.; Bennett, R.N.; Mota, M.; Figueiredo, A.C. Bioactivity against Bursaphelenchus xylophilus: Nematotoxics from essential oils, essential oils fractions and decoction waters. Phytochemistry 2013, 94, 220-228. [CrossRef] [PubMed]

115. Faria, J.M.S.; Sena, I.; Moiteiro, C.; Bennett, R.N.; Mota, M.; Figueiredo, A.C. Nematotoxic and phytotoxic activity of Satuyreja montana and Ruta graveolens essential oils on Pinus pinaster shoot cultures and P. pinaster with Bursaphelenchus xylophilus in vitro co-culture. Ind. Crop. Prod. 2015, 77, 59-65. [CrossRef]

116. Laquale, S.; Candido, V.; Avato, P.; Argentieri, M.P.; D'Addabbo, T. Essential oils as soil biofumigants for the control of the root-knot nematode Meloidogyne incognita on tomato. Ann. Appl. Biol. 2015, 167, 217-224. [CrossRef]

117. Drioueche, A.; Boutoumi, H.; Boucherit, A. The performance of the Ruta montana L. essential oil bisulfite adduct as mixed natural emulsifier and comparison with single tailed surfactant. J. Dispers. Sci. Technol. 2019, 41, 2159-2168. [CrossRef]

118. Nahar, L.; Sarker, S.D. Nanotechnology and oral health. In Nanotechnology-Based Drug Delivery Systems; Talukdar, A.D., Sarker, S.D., Patra, J.K., Eds.; Elsevier: Berkeley, CA, USA, 2021; in press.

119. Sarker, S.D.; Nahar, L. Characterization of nanoparticles. In Nanotechnology-Based Drug Delivery Systems; Talukdar, A.D., Sarker, S.D., Patra, J.K., Eds.; Elsevier: Berkeley, CA, USA, 2021; in press.

120. Zhang, F.; Ramachandran, G.; Mothana, R.A.; Noman, O.M.; Alobaid, W.A.; Rajivgandhi, G.; Manoharan, N. Antibacterial activity of chitosan loaded plant essential oil against multi drug resistant K. Pneumoniae. Saudi J. Biol. Sci. 2020, 27, 3449-3455. [CrossRef]

121. Barrera-Ruiz, D.G.; Cuestas-Rosas, G.C.; Sanchez-Martinez, R.I.; Alvarez-Ainza, M.L.; Moreno-Ibarra, G.M.; Lopez-Meneses, A.K.; Plascencia-Jatomea, M.; Cortez-Rocha, M.O. Antibacterial activity of essential oils encapsulated in chitosan nanoparticles. Food Sci. Technol. 2020, 40, 568-573. [CrossRef]

122. Tovar, C.D.G.; Delgado-Ospina, J.; Porras, D.P.N.; Peralta-Ruiz, Y.; Cordero, A.P.; Castro, J.I.; Valencia, M.N.C.; Mina, J.H.; Lopez, C.C. Colletotrichum gloeosporioides inhibition in situ by chitosan-Ruta graveolens essential oil coatings: Effects on microbiological, physicochemical, and organoleptic properties of guava (Psidium guajava L.) during room temperature storage. Biomolecules 2019, 9, 399. [CrossRef]

123. Peralta-Ruiz, Y.; Tovar, C.D.G.; Sinning-Mangonez, A.; Coronell, E.A.; Marino, M.F.; Chavez-Lopez, C. Colletotrichum gloeosporioides inhibition using chitosan-Ruta graveolens L. essential oil coatings: Studies in vitro and in situ on Carica papaya fruit. Int. J. Food Microbiol. 2020, 326, 108649. [CrossRef]

124. Gonzalez-Locarno, M.; Pautt, Y.M.; Albis, A.; Lopez, E.F.; Tovar, C.D.G. Assessment of chitosan-Rue (Ruta graveolens L.) essential oil-based coatings on refrigerated cape gooseberry (Physalis peruviana L.) quality. Appl. Sci. 2020, 10, 2684. [CrossRef]

125. Peralta-Ruiz, Y.; Tovar, C.D.G.; Sinning-Mangonez, A.; Coronell, E.A.; Marino, M.F.; Chavez-Lopez, C. Reduction of post-harvest quality loss and microbiological decay of tomato "Chonto" (Solanum lycopersicum L.) using chitosan-essential oil-based edible coatings under low temperature storage. Polymers 2020, 12, 1822. [CrossRef] [PubMed] 